DEVELOPMENT OF A DATA BASE OF

COMMUNITY WATER-SUPPLY WELLS IN

NEW JERSEY AND A METHOD TO EVALUATE

THEIR SENSITIVITY TO CONTAMINATION

By Donald A. Storck, Kalman N. Isaacs, and Eric F. Vowinkel

U.S. GEOLOGICAL SURVEY

Water-Resources Investigations Report 96-4132

Prepared in cooperation with the NEW JERSEY DEPARTMENT OF ENVIRONMENTAL PROTECTION 


\section{U.S. DEPARTMENT OF THE INTERIOR \\ Bruce Babbitt, Secretary}

\section{U.S. GEOLOGICAL SURVEY}

Gordon P. Eaton, Director

For additional information write to:

District Chief U.S. Geological Survey, WRD Mountain View Office Park 810 Bear Tavern Road Suite 206

West Trenton, NJ 08628
Copies of this report can be purchased from:

U.S. Geological Survey Branch of Information Services Box 25286, MS 517

Denver, CO 80225 


\section{CONTENTS}

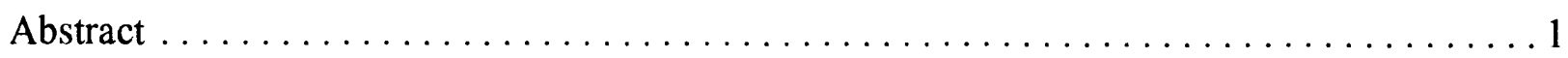

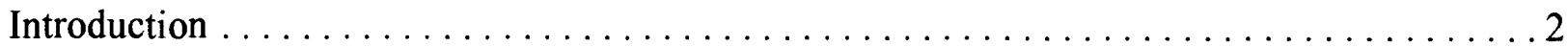

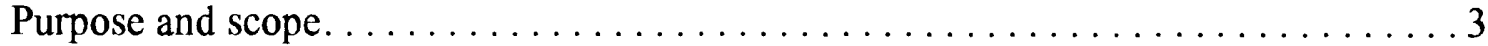

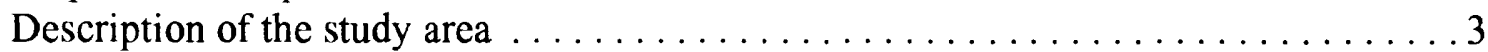

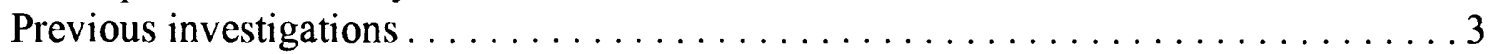

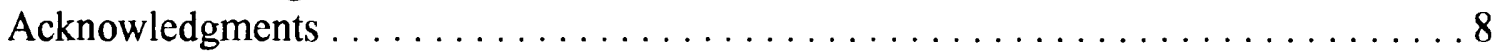

Development of the water-supply-well data base $\ldots \ldots \ldots \ldots \ldots \ldots \ldots \ldots \ldots \ldots$

Sources of well-construction and other well-attribute data $\ldots \ldots \ldots \ldots \ldots \ldots \ldots$

Components of the data base $\ldots \ldots \ldots \ldots \ldots \ldots \ldots \ldots \ldots \ldots \ldots \ldots$

Method to evaluate the sensitivity of wells to contamination $\ldots \ldots \ldots \ldots \ldots \ldots \ldots$

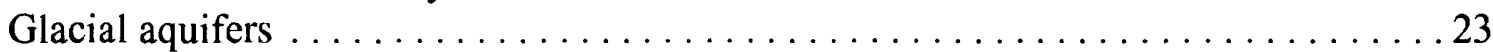

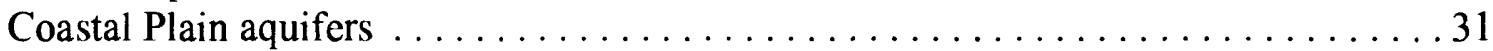

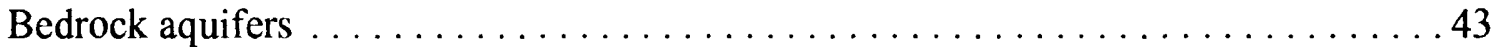

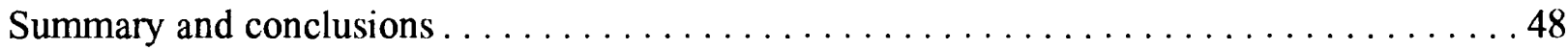

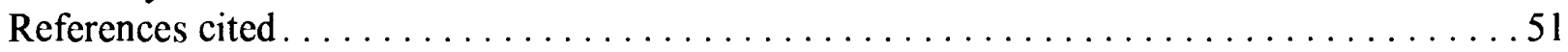

\section{ILLUSTRATIONS}

Figure 1. Map showing physiographic provinces and distribution of community watersupply wells in New Jersey. . . . . . . . . . . . . . . 4

2. Flow chart showing sources of well-construction and other well-attribute data stored in the water-supply-well data base . . . . . . . . . . . . 10

3. Schematic diagram showing method used to determine sensitivity of community water-supply wells in New Jersey to contamination from land surface. . . . . . . . . . . . . . . . . . . . . . . . . 17

4. Boxplots showing distributions of well depth, depth to the top of the open interval, and length of the open interval for wells in glacial, Coastal Plain, and bedrock aquifers, New Jersey . . . . . . . . . . . . . . . 22

5. (A) Map showing distribution of tritium concentrations in water samples from sampled wells, and (B) boxplots showing distributions of tritium concentrations in water samples from wells with open intervals in glacial aquifers, the Kirkwood-Cohansey aquifer system, and bedrock aquifers . . . . . . . 24

6. Map showing extent of glacial sediments in northern New Jersey. . . . . . . . 26

7. Generalized hydrogeologic section showing aquifer and confining-unit geometry and ground-water flow paths in glacial aquifers in northern New Jersey .

8. Map showing simulated ground-water contributing areas and travel times for wells 27-82, 27-83, and 27-86 in a glacial aquifer at Picatinny Arsenal, Morris County, New Jersey . . . . . . . . . . . . . . . . . . . 28

9. Boxplots showing distributions of simulated ground-water travel times for three wells at Picatinny Arsenal, Morris County, New Jersey . . . . . . . . . . . 30

10. Generalized hydrogeologic section showing major aquifers and confining units in the New Jersey Coastal Plain . . . . . . . . . . . . . . . 32 


\section{ILLUSTRATIONS--Continued}

Figure 11. Map showing ground-water travel time through the Merchantville-Woodbury confining unit in the New Jersey Coastal Plain ................ 34

12. Map showing ground-water travel time through the composite confining unit in the New Jersey Coastal Plain. .................... 35

13. Map showing simulated ground-water contributing area and travel time to well 15-69 in a Coastal Plain aquifer system, Gloucester County, New Jersey. ................................ 36

14. Map showing simulated ground-water contributing area and travel time to well 15-212 in a Coastal Plain aquifer system, Gloucester County, New Jersey................................ 38

15. Map showing simulated ground-water contributing areas and travel time to well 15-348 in a Coastal Plain aquifer system, Gloucester County, New Jersey.................................. 39

16. Map showing locations of selected wells in and downdip from the outcrop of the Potomac-Raritan-Magothy aquifer system in Gloucester County, New Jersey. ................................ 40

17. Boxplots showing distributions of ground-water travel times to selected wells in and downdip from the outcrop of the Potomac-Raritan-Magothy aquifer system, New Jersey........................... 41

18. Generalized hydrogeologic section showing ground-water flow paths in bedrock aquifers .................................. 45

19. Map showing simulated ground-water contributing area for well 27-1727 in a bedrock aquifer system, Morris County, New Jersey ............. 46

20. Boxplot showing distribution of ground-water travel times to a well in a bedrock aquifer system in Morris County, New Jersey ................ 47

\section{TABLES}

Table 1. Stratigraphic and hydrogeologic characteristics of geologic units in New Jersey. . . 6

2. Items stored in the water-supply-well data base for New Jersey, sources of data,

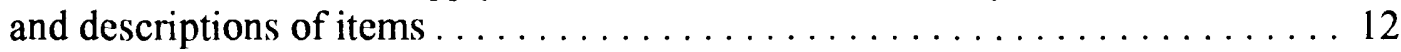

3. Items added to the water-supply-well data base by the New Jersey Geological

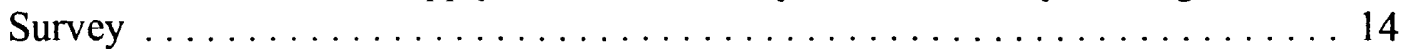

4. Number of wells in glacial and Coastal Plain aquifers in New Jersey in the water-supply-well data base, and number of wells that are sensitive to con-

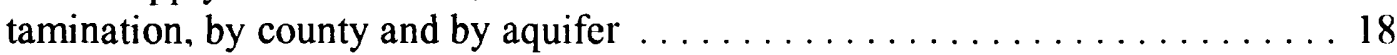

5. Number of wells in bedrock aquifers in New Jersey in the water-supply-well data base, by county and by aquifer. . . . . . . . . . . . . . . 20

6. Sclected well-construction data and simulated ground-water travel times for community water-supply wells screened in glacial and bedrock aquifers in Morris County, New Jersey . . . . . . . . . . . . . . . . . . . . . . 29 


\section{TABLES--Continued}

Page

Table 7. Selected well-construction data and simulated ground-water travel times for community water-supply wells screened in the Potomac-Raritan-Magothy aquifer system in Gloucester County, New Jersey. . . . . . . . . . . . . . 42

8. Selected well-construction data and simulated ground-water travel times for a community water-supply well open to a bedrock aquifer in Morris County, New Jersey 


\title{
DEVELOPMENT OF A DATA BASE OF COMMUNITY WATER-SUPPLY WELLS IN NEW JERSEY AND A METHOD TO EVALUATE THEIR SENSITIVITY TO CONTAMINATION
}

\author{
By Donald A. Storck, Kalman N. Isaacs, and Eric F. Vowinkel
}

\begin{abstract}
Well-construction and other well-attribute data for 2,598 community water-supply wells in New Jersey were compiled from existing data bases. The resulting data base is stored in a geographic information system and includes well-identification numbers, well-construction details and well characteristics, ratings of sensitivity to contamination, location data, and owner information. Information from this data base can be used by water managers to delineate wellhead-protection areas for water-supply wells.
\end{abstract}

Ground-water flow models were used to simulate ground-water contributing areas and the travel times of ground water from the water table to the open interval of wells in typical aquifer settings. From this information, the sensitivity to contamination of wells in three types of aquifers--glacial, Coastal Plain, and bedrock--was evaluated. Hydrogeologic variables that were considered in this assessment include the presence or absence of confining units above the open interval of the well, the location of the well relative to the outcrop area of the aquifer penetrated by the well, and the depth to the top of the open interval.

Wells with open intervals in glacial aquifers were considered to be sensitive to contamination from land surface because of (1) the absence of extensive confining units; (2) short groundwater travel times from the water table to the well; and (3) the typical construction characteristics of wells in glacial aquifers, which include shallow depth to the top of the open interval and shallow depth of the well. Wells screened in Coastal Plain aquifers were considered either (1) sensitive (wells in or less than 0.5 miles downdip from outcrop areas of confined aquifers and wells in unconfined aquifers, because the minimum travel time from land surface to the well likely is less than 12 years), or (2) insensitive (wells in confined aquifers greater than 0.5 miles downdip from the outcrop area, because the minimum travel time likely is greater than 12 years). Wells with open intervals in bedrock aquifers were considered sensitive to contamination because of (1) the geologic complexity of aquifer systems and absence of extensive confining units; (2) the relatively fast velocities of ground water in fractured zones within bedrock aquifers and the resulting short travel time of ground water from land surface to the wells; and (3) the typical construction characteristics of wells in bedrock aquifers, such as long open intervals and short casing lengths. All 245 wells in glacial and 1,002 wells in bedrock aquifers were considered sensitive to contamination because minimum travel times are most likely less than 12 years. In the Coastal Plain, 637 of 1,351 wells were considered sensitive to contamination because they are located in outcrop areas or less than 0.5 miles downdip from outcrop areas where minimum travel times are probably less than 12 years. 


\section{INTRODUCTION}

The New Jersey Department of Environmental Protection (NJDEP) is responsible for ground-water protection and resource management within the State of New Jersey. The NJL GP developed a Wellhead Protection Program Plan as required by the 1986 Federal Safe Drinking Water Act Amendments (Section 1428). The purpose of the Wellhead Protection Program is to minimize the risk of water-supply-well contamination due to the discharge of ground-water contaminants at land surface. The Wellhead Protection Program was developed to enhance protection of three groups of potable-water-supply wells: public community supply wells, public noncommunity supply wells, and clusters of domestic supply wells. It provides this protection through the delineation of wellhead-protection areas and the implementation of regulations and other activities to minimize contamination from both point and nonpoint sources within these areas (New Jersey Department of Environmental Protection and Energy, 1991).

Wellhead-protection areas, as defined by the NJDEP, are portions of the wells' groundwater contributing areas that are close to the wells. A wellhead-protection area is defined by two criteria: the average time of travel for ground water to reach a well from the water table, and the presence of hydrologic boundaries, such as faults, surface-water bodies, and confining units. Each wellhead-protection area is divided into three sequential tiers. Management controls are most stringent nearest the well, because contaminant sources near a well pose the greatest threat to ground-water quality. Tier 1 is intended to prevent sources of bacteria and viruses from discharging near the well; the travel time from its outer boundary to the well is 200 days. Tier 2 is intended to prevent discharges of hazardous materials that do not degrade rapidly in ground water in areas so close to the well that remediation is not possible; the time of travel from its outer boundary to the well is 5 years. Tier 3 is designed to allow remediation of contaminant discherges before the well is contaminated if the discharge can be identified and responded to rapidly; the maximum time of travel from Tier 3 is 12 years. The time-of-travel criterion results in wellheadprotection areas that are tailored to individual wells and are based on the well's pumping cape city, the length of the well's open interval, the characteristics of the surrounding aquifer, and other variables specific to that well (New Jersey Department of Environmental Protection and Energy, 1991).

To effectively manage and protect the ground-water resources of the State, an understanding of the sensitivity of aquifers and wells to contamination is necessary. The sensitivit' of wells to contamination is related to hydrogeologic factors that determine the time of travel of water recharged from land surface to the open interval of the well. Hydrogeologic variables that may affect the time of travel are soil type, depth to water, depth to the top of the open interval, hydraulic properties of aquifers, position of the well within the flow system, and the presence of confining units above the open interval.

The NJDEP Wellhead Protection Program establishes wellhead-protection areas on tl' $\mathrm{e}$ basis of the assumptions that the recharge area of the well is in the immediate vicinity of the well, and that the protection area includes only those areas within a 12-year travel time of the well (New Jersey Department of Environmental Protection and Energy, 1991). Under this definition, community water-supply wells may be exempt from Wellhead Protection Program delineaticn regulations because the recharge area of the well is likely to be far from the well itself, and because ground-water travel time from the land surface to the well exceeds 12 years. 
The NJDEP, Bureau of Safe Drinking Water (BSDW), currently monitors the quality of water in about 2,600 public community supply wells in New Jersey (fig. 1). Well-construction, well-location, and other well-attribute data for these wells reside in various locations and formats, and are associated with varying degrees of accuracy and completeness. Therefore, the U.S. Geological Survey (USGS), in cooperation with the NJDEP, conducted an investigation during 1992-95 to (1) compile and organize a data base of well-construction and other well-attribute data for community water-supply wells within the State of New Jersey, and (2) develop methods to determine the sensitivity of these wells to contaminants discharged at land surface. This information can be used by water managers to appropriately delineate wellhead-protection areas for water-supply wells that are contamination-sensitive, and to exempt from wellhead-protection delineation regulations those wells that withdraw water from parts of aquifer systems that are insensitive to contamination.

\section{Purpose and Scope}

This report describes the sources of well-construction and other well-attribute data that were compiled in, and components of, a data base of 2,598 community water-supply wells in New Jersey. It also describes the method used to evaluate the sensitivity to contamination of wells in three types of aquifers: glacial, Coastal Plain, and bedrock. Also included are examples of areas contributing water to wells and times of travel of ground water for selected wells in these types of aquifers determined by using available ground-water flow models. In addition, the report also presents guidelines for determining the sensitivity to contamination of wells screened in confined aquifers.

\section{Description of the Study Area}

New Jersey is divided into four well-defined physiographic provinces that trend from northeast to southwest: the Valley and Ridge, Highlands, Piedmont, and Coastal Plain Provinces. For this evaluation, aquifers and aquifer systems in these provinces are classified into three types --glacial, Coastal Plain, and bedrock--on the basis of similarities in hydrogeologic characteristics of the aquifers and typical well-construction characteristics. The stratigraphic and hydrogeologic characteristics of the geologic units in New Jersey are shown in table 1.

\section{Previous Investigations}

Previous investigations relevant to the current study are of four types: (1) evaluations of approaches and methods used to assess the sensitivity of aquifers and the vulnerability of ground water to contamination, (2) studies in which statistical and ground-water flow models were used to assess ground-water vulnerability and delineate ground-water contributing areas in New Jersey and hydrogeologically similar nearby areas, (3) studies in which ground-water flow models were developed to describe flow conditions in various parts of New Jersey, and (4) hydrogeologic investigations of various parts of New Jersey.

Many approaches and methods have been used to assess the sensitivity of aquifers and the vulnerability of ground water to contamination. These methods range in complexity from simple evaluations of available map data to complex models of physical, chemical, and biological 


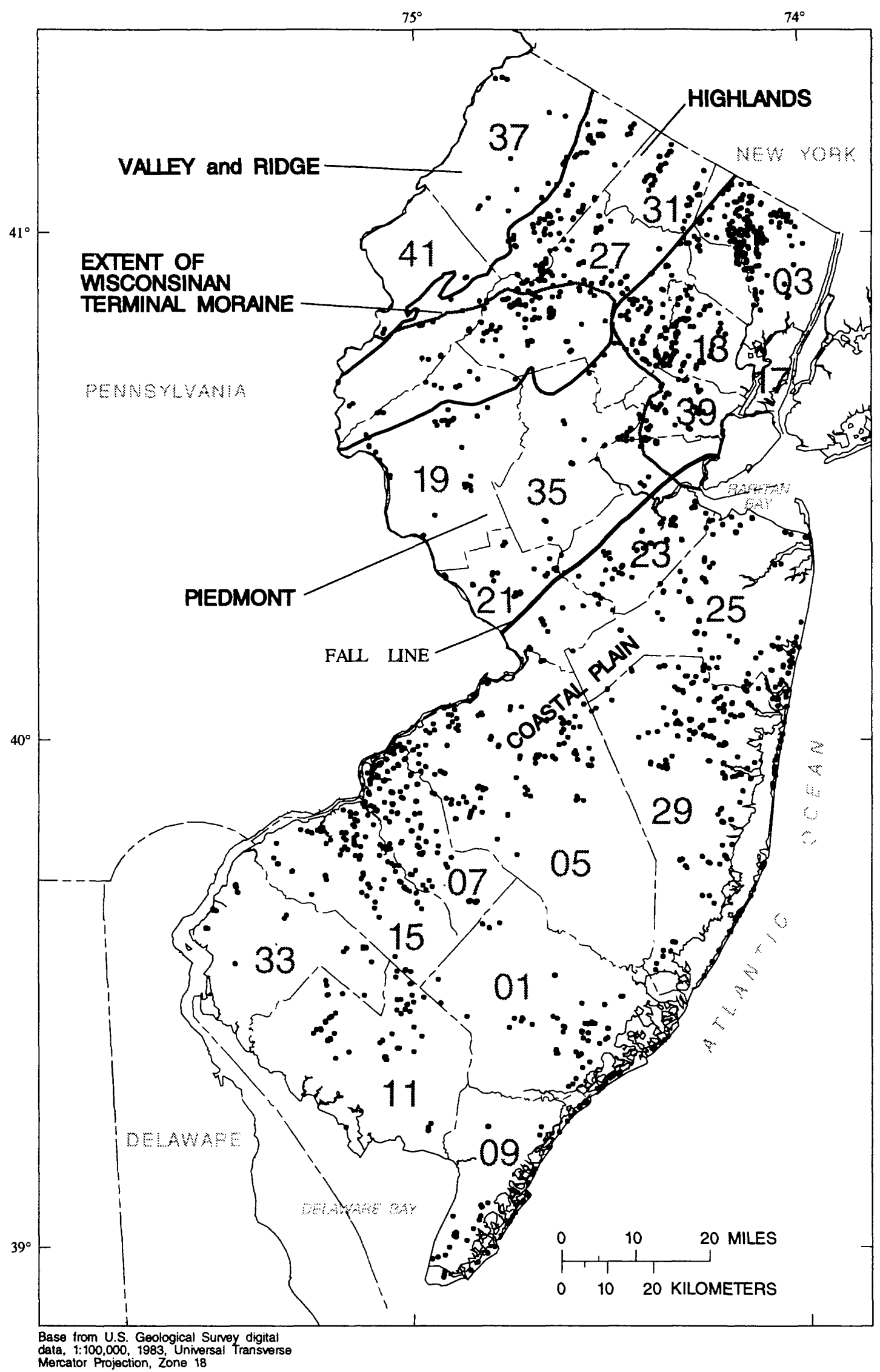

Figure 1. Physiographic provinces and distribution of community water-supply wells in New Jersey. (County names and codes are listed in table 1.) 
processes that occur in ground-water systems and the unsaturated zone. The U.S. Environmental Protection Agency (1992) evaluated the methods currently available to assess aquifer sensitivity or ground-water vulnerability to pesticide contamination. The vulnerability of wells is determined on the basis of the sensitivity of the aquifer to contamination and the intensity of land use in areas where the aquifer is sensitive. The methods evaluated include aquifer-sensitivity methods, which consider hydrogeologic factors only; hybrid methods, which consider hydrogeologic and chemical factors; and ground-water-vulnerability assessment methods, which consider hydrogeologic, pesticide, and agronomic factors. The National Research Council (1993) evaluated assessment methods in three general categories, including overlay and index methods, methods employing process-based simulation models, and statistical models. Overlay and index methods are based on combining maps of various physiographic attributes by assigning a numerical index or score to each attribute. Process-based simulation model methods require the use of analytical or numerical solutions to mathematical equations that represent processes that control contaminant transport. Statistical methods incorporate data on known contaminant distributions and characterize contamination potential for the specific geographic area from which the data were collected.

Statistical models and ground-water flow models that incorporate hydrogeologic characteristics have been used to assess ground-water vulnerability. Vowinkel and others (1994) used a geographic information system (GIS) in conjunction with a numerical rating model to determine the vulnerability of community water-supply wells in New Jersey to contamination by pesticides. Nitrate was used as a surrogate for pesticide contamination, and the vulnerability rating was based on the sensitivity of the aquifer and the intensity of land use in sensitive areas. The results showed that only 1 of 134 wells more than $0.5 \mathrm{mi}$ downdip from the outcrop of the Magothy Formation yielded water samples with nitrate concentrations greater than $0.5 \mathrm{mg} / \mathrm{L}$. Vowinkel and Battaglin (1989) used nonparametric statistical procedures to determine significant hydrogeologic conditions, well-construction characteristics, and land-use variables that affect the presence and distribution of purgeable organic compounds in ground water. Risser and Madden (1994) used a numerical ground-water flow model to compare methods to delineate areas of diversion and contributing areas for wells screened in glacial-aquifer systems. They described and compared fixed-radius, uniform-flow, analytical, semianalytical, and numerical-modeling methods.

Many ground-water flow models developed to describe ground-water flow conditions in areas of New Jersey can be used to assess ground-water vulnerability and sensitivity. Navoy (1994) used a finely discretized ground-water flow model to show that the zone of nonpointsource contamination extends a maximum of 0.5 to $2 \mathrm{mi}$ downdip from the outcrop area of the Potomac-Raritan-Magothy system in Gloucester County. The areas contributing water to watersupply wells were determined by flow-path simulation by use of particle-tracking analysis. D.A. Pope and others (U.S. Geological Survey, written commun., 1994) simulated ground-water flow and the movement of the saltwater/freshwater interface in 10 aquifers and 10 confining units in the New Jersey Coastal Plain. They demonstrated that water moves vertically through a confining unit in less than 12 years only in the immediate vicinity of the aquifer outcrop. The maximum distance from the margin of the outcrop for a travel time of 12 years or less was similarly shown to be about $2 \mathrm{mi}$. Nicholson and others (1996) used a finite-difference model to simulate groundwater flow in three aquifers and two intervening confining units in a carbonate-rock and valley-fill aquifer system in the New Jersey Highlands. Particle-tracking analysis was used to 


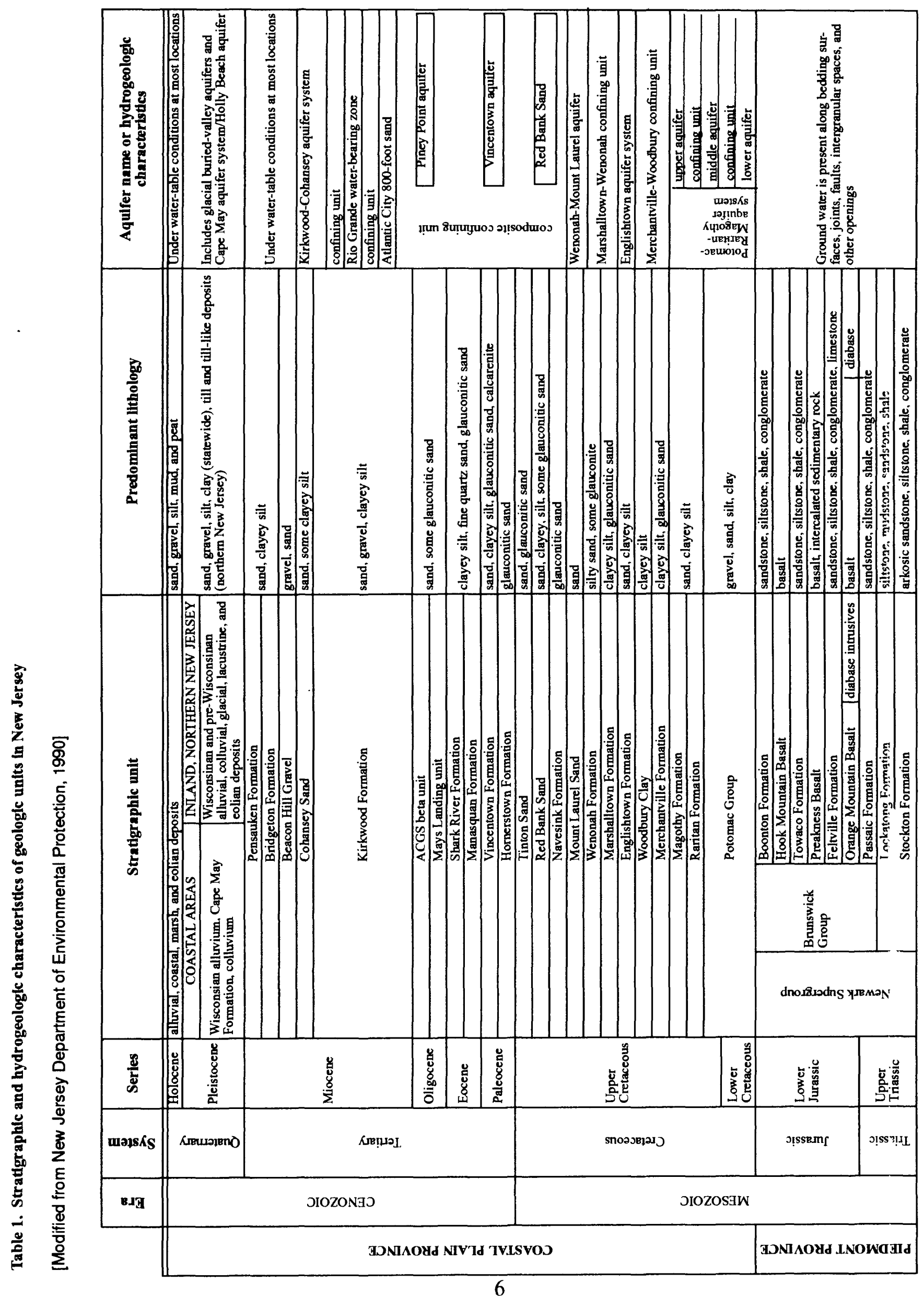



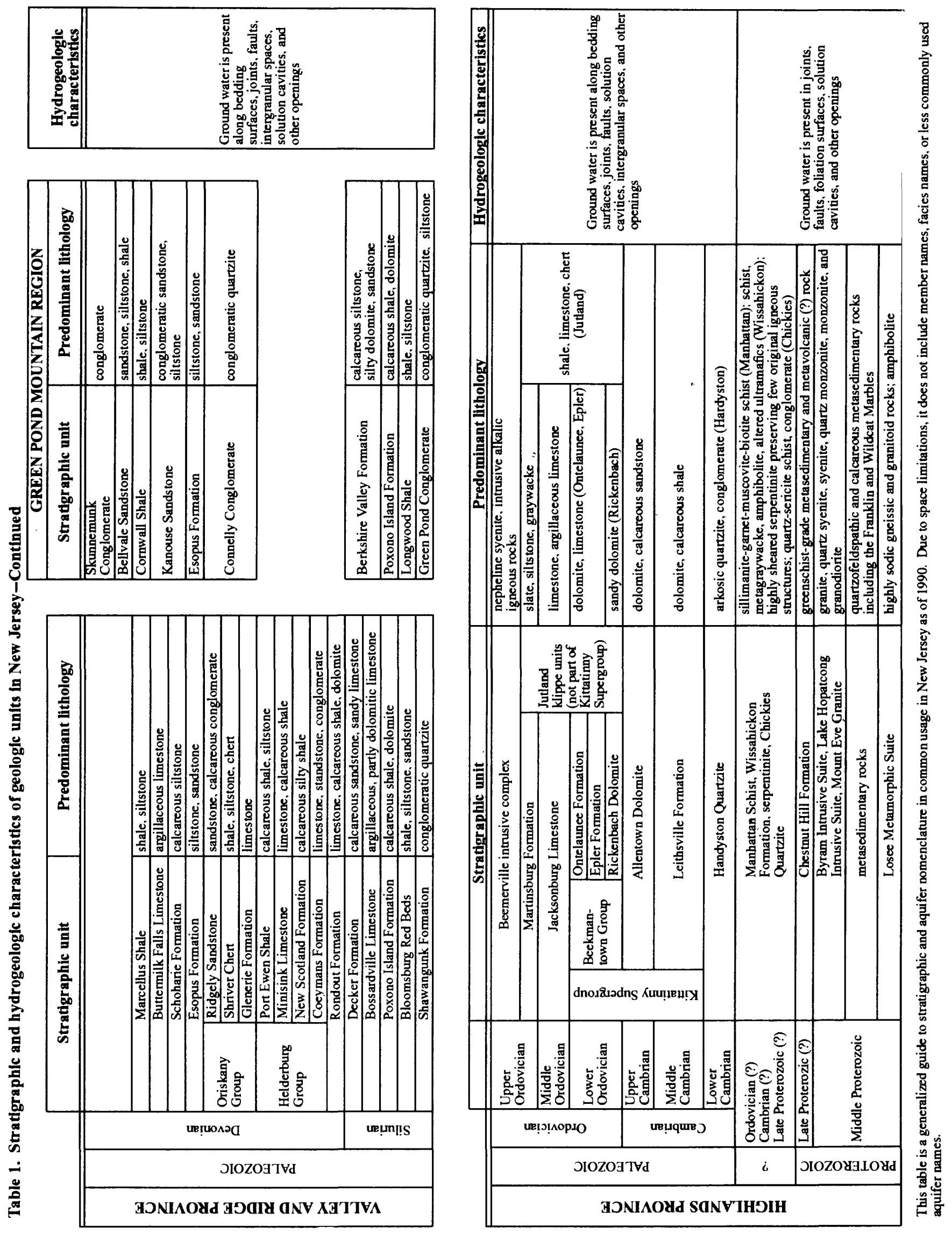
delineate areas contributing water to wells. D.E. Rice and L.M. Voronin (U.S. Geological Sur'ey, written commun., 1995) used a three-dimensional finite-difference model to simulate groundwater flow under steady-state pumping conditions in glacial and bedrock aquifers at Picatinny Arsenal, New Jersey. A particle-tracking, flow-path analysis of simulated results for selected pumping alternatives was used to determine contributing areas of water-supply wells and travel times of ground water from contributing areas to the wells. Hill and others (1992) used a thre?dimensional numerical model to quantify hydrogeologic characteristics of the ground-water system and to evaluate the hydrologic relation between ground-water withdrawals and streamf ${ }^{\prime} \mathrm{ow}$ in valley-fill deposits in the Ramapo River Valley. In the northern part of the valley, a silt and clay layer locally confines a basal sand and gravel layer. Aquifer-test data were used to determine that recharge to the basal layer through the confining unit was less than recharge around its edges. Martin (1990) simulated ground-water flow in 10 aquifers and 9 intervening confining units of the New Jersey Coastal Plain by using a multilayer finite-difference model. Lacombe and Carletcn (U.S. Geological Survey, written commun., 1995) present a detailed description of aquifers and confining units in Cape May County that includes maps of the tops of units, thickness of units, potentiometric surfaces, and areas affected by saltwater intrusion.

Many reports and maps have described the hydrology and hydrogeology of New Jersev. These reports were used to evaluate the sensitivity of wells to contamination and to determine the aquifers in which new wells compiled as part of this study were completed or are open. Zapecza (1989) described the hydrogeologic framework of the entire Coastal Plain of New Jersey. This investigation used borehole geophysical data to define the presence and configuration of 15 regional hydrogeologic units. Barton and Kozinski (1991) investigated the hydrogeology of Greenwich Township, in Gloucester County. Lewis and others (1991) studied the hydrogeology and ground-water quality of the Potomac-Raritan-Magothy aquifer system in the Logan Township area of western Gloucester and northern Salem Counties. Gronberg and others (1991) studied the hydrogeologic framework of the Potomac-Raritan-Magothy aquifer system in the northern part of the New Jersey Coastal Plain. Geologic maps and reports were used to determine geologic units and aquifer codes for new wells in non-Coastal Plain areas of the State that were compiled as part of this study. Aquifer codes stored in the water-supply-well data base represent the geologic unit in which the open interval of the well is found. The maps used include the Newark $1^{\circ} \times 2^{\circ}$ Quadrangle, New Jersey, Pennsylvania, and New York (Lyttle and Epstein, 1987), Green Pond Mountain region from Dover to Greenwood Lake, New Jersey (Herman and Mitchell, 1991), Stanhope Quadrangle, Sussex and Morris Counties, New Jersey (Volkert and others, 1989), Franklin and parts of Hamburg Quadrangles, New Jersey (Buddington and Baker, 1961), Branchville Quadrangle, Sussex County, New Jersey (Drake and Monteverde, 1992), Bloomsbirry Quadrangle, New Jersey (Drake, 1967a), Easton Quadrangle, New Jersey (Drake, 1967b), and Newton West Quadrangle, Sussex and Warren Counties, New Jersey (Drake, 1992). Miller (1974) presents the geology and ground-water resources of Sussex and parts of Warren Counties and includes a geologic and a depth-to-bedrock map.

\section{Acknowledgments}

The authors extend their appreciation to Theresa Romagna and Kim Cenno of the NJDEP, Office of Environmental Planning, for their guidance in the planning and implementation of th is investigation. Thanks also are extended to William Mennel and Steven Spayd of the NJDEP, New 
Jersey Geological Survey (NJGS), for their assistance with the data base and for supplying global-positioning-system location data for many of the wells. Thanks also to Richard Kropp, Jan Gheen, Gail Witkowski, and other personnel of the NJDEP, Bureau of Water Allocation for their guidance in the collection of well records and well permits from their data base of community water-supply wells, and for supplying computerized versions of their data base for these wells.

\section{DEVELOPMENT OF THE WATER-SUPPLY-WELL DATA BASE}

A data base containing well-construction and other well-attribute data for community water-supply wells in New Jersey was developed. Items stored in the data base include wellidentification numbers, well-construction details and other well characteristics, rating of sensitivity to contamination, location data, and owner information. This data base is stored in a GIS as an ARC/INFO ${ }^{1}$ point coverage and includes information from the USGS National Water Information System (NWIS) Ground Water Site Inventory (GWSI) data base stored in a point-attribute table. Information compiled from other data bases and files from various State agencies that is not in the GWSI data base is stored in related INFO data files. The water-supply-well data base ultimately will reside with, and be maintained by, the NJGS.

\section{Sources of Well-Construction and Other Well-Attribute Data}

The sources of well-construction and other well-attribute data in the water-supply-well data base are (1) the NJDEP Bureau of Safe Drinking Water (BSDW) SOURCE data base, (2) the NJDEP Bureau of Water Allocation data bases WATERA and WSOURCE, and (3) the USGS GWSI data base (fig. 2). Information also was compiled from survey questionnaires that were distributed by the BSDW to gather information on public water systems and were completed by purveyors or owners, and from BSDW field inspection reports. Additional information stored in the water-supply-well data base was compiled directly from well permits and well records.

Data were compiled for wells that meet the BSDW definition of a public community supply well--that is, any well that is used to supply water for human consumption on a year-round basis to 25 or more people, or that has 15 or more service connections. The water-supply-well data base was created from the list of active community water-supply wells in the BSDW SOURCE data base by adding new wells and additional data from GWSI, WSOURCE, and BSDW inspection reports, survey questionnaires, well permits and well records, and other minor sources. The BSDW definition includes many low-capacity wells that are used by trailer parks and homeowner associations, for example, that are not included in WSOURCE, the Bureau of Water Allocation data base for public community supply wells. Because the Bureau of Water Allocation defines a public community supply well as any well that supplies water for human consumption and produces at least $100,000 \mathrm{gal} / \mathrm{d}$ or $70 \mathrm{gal} / \mathrm{min}$, WSOURCE includes only wells owned by major water companies, water departments, and some of the larger trailer parks and homeowner associations.

${ }^{1}$ The use of brand or trade names in this report is for identification purposes only and does not constitute endorsement by the U.S. Geological Survey. 


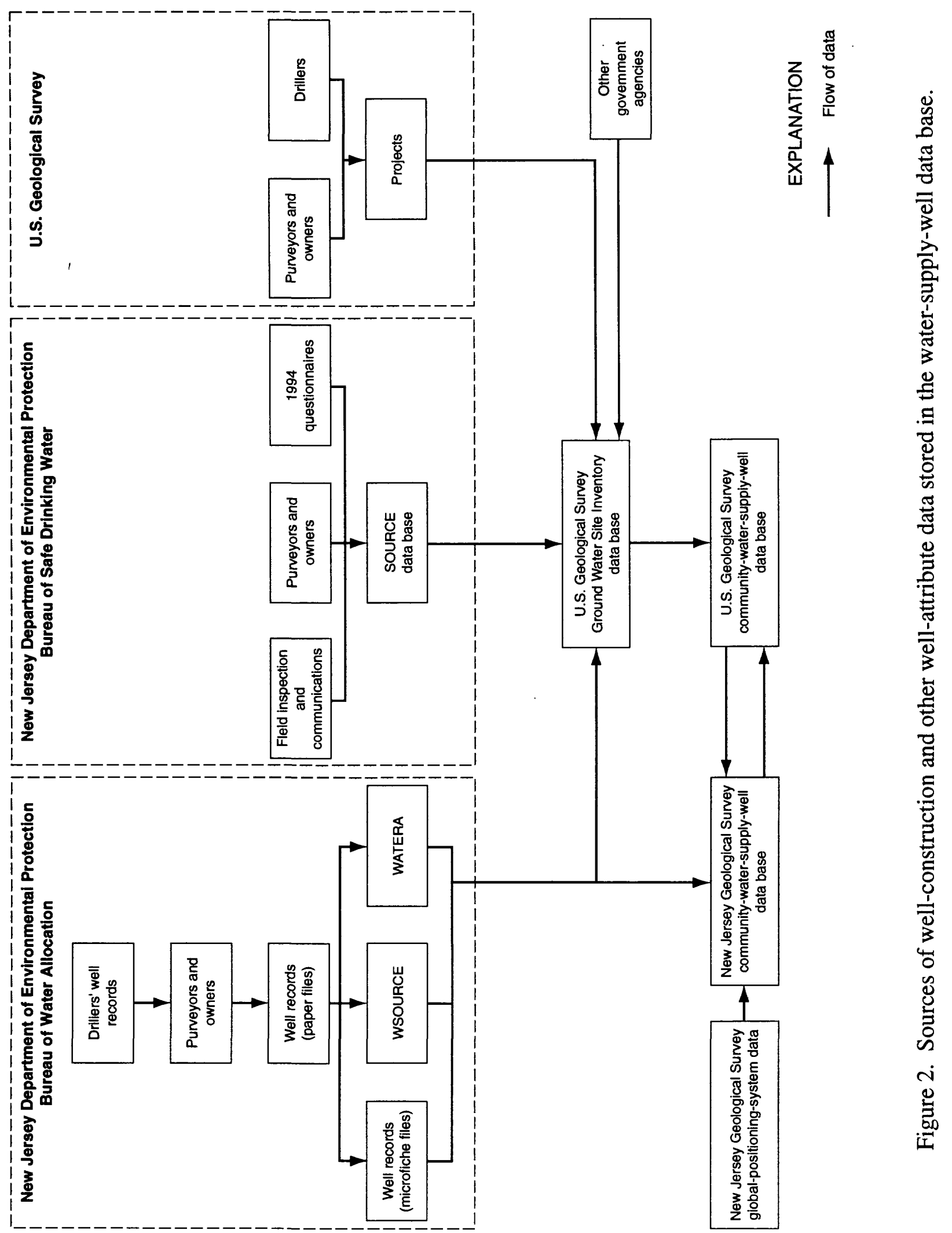


The BSDW SOURCE data base contains information about owners or purveyors, and well-construction and other well-attribute data for public water systems and treatment facilities. It consists of information collected from Bureau of Water Allocation data bases, from periodic field inspections, and from other sources.

The Bureau of Water Allocation WATERA and WSOURCE data bases contain information about the well owners or purveyors, and well-construction and other well-attribute data for individual wells, respectively. These data bases include information for several types of wells monitored by the Bureau, including public supply, industrial, irrigation, observation, and other types of wells. The source of much of the data for wells maintained in WATERA and WSOURCE data bases is well records and permits submitted by the driller, and correspondence between the purveyors and the Bureau during the water-allocation permitting process. When a new well is installed, the well driller is required to submit information about the well to the Bureau, including construction details, owner information, and location data.

The USGS GWSI data base, a National ground-water data storage and retrieval system, contains well-construction and other well-attribute data (Mathey, 1990). This data base contains information on all types of wells, including public supply, observation, domestic, industrial, and other types of wells. These data were collected over many years, from owners, drillers, State agencies, and other sources. Selected information for community water-supply wells was retrieved from the GWSI data base and transferred into the water-supply-well data base. When a well record and well permit were found for a new well, information from them was coded on a GWSI entry form. Other information, such as aquifer codes, elevation, and location data, was determined from existing published reports and maps described in the Previous Investigations section of this report. The form was then submitted to the USGS, New Jersey District, GWSI data-base administrator for verification and entry into the GWSI data base. Methods used to determine the sensitivity rating are described in a later section of this report.

\section{Components of the Data Base}

Information for all community water-supply wells in New Jersey was collected and compiled from the sources listed above. Most components of the water-supply-well data base--for example, well-identification numbers--were found in only one source, and are unique to that source. The information that appeared to be most accurate and reliable was entered into the watersupply-well data base when conflicting values were found in two or more sources.

Items that are stored in the water-supply-well data base for each community water-supply well in New Jersey, the sources of the data and the priorities of the sources used, if applicable, and a brief description of the item are presented in table 2 . The NJGS maintains its own version of the water-supply-well data base, which is based on the USGS version. Items added to the data base and items modified by the NJGS are presented in table 3 . 
Table 2. Items stored in the water-supply-well data base for New Jersey, sources of data, and descriptions of items

[GWSI, Ground Water Site Inventory data base; BSDW, Bureau of Safe Drinking Water; BWA, Bureau of Water Allocation; NJGS, New Jersey Geological Survey]

\begin{tabular}{|c|c|c|}
\hline Data-base item & $\begin{array}{c}\text { Source(s) of } \\
\text { data }\end{array}$ & Description of item \\
\hline \multicolumn{3}{|c|}{ Identification numbers and names, and well characteristics } \\
\hline Unique identifier & GWSI & $\begin{array}{l}\text { Six-digit number that identifies an individual well in GWSI. The } \\
\text { first two digits represent the county in which the well is loca }{ }^{+e d} \text {; } \\
\text { the last four are sequentially assigned when entered into GW'SI. } \\
\text { County codes are given in table } 1 \text {. }\end{array}$ \\
\hline Site identifier & GWSI & $\begin{array}{l}\text { Fifteen-digit code used as the primary identifier of a well in } \\
\text { GWSI. }\end{array}$ \\
\hline Public water supply number & BSDW & $\begin{array}{l}\text { Seven-digit number assigned by BSDW that identifies a } \\
\text { public-water-supply system. The first four digits represent } t l o \\
\text { county and municipality in which the well is located; the las } \\
\text { three digits are sequentially assigned. }\end{array}$ \\
\hline SF ID & BSDW & $\begin{array}{l}\text { Number assigned by BSDW that identifies an individual we'l } \\
\text { within a public-water supply system. }\end{array}$ \\
\hline Water allocation number & BWA & $\begin{array}{l}\text { Number assigned by BWA to identify a well or group of we'ls } \\
\text { covered under a water-allocation permit. }\end{array}$ \\
\hline Permit number & $\begin{array}{l}\text { BWA, GWSI, } \\
\text { BSDW }\end{array}$ & $\begin{array}{l}\text { Number assigned by BWA prior to well installation that is the } \\
\text { N.J. Department of Environmental Protection primary } \\
\text { identifier of a well. The first two digits represent the State Atlas } \\
\text { Map on which the well is located; the last five digits are } \\
\text { assigned sequentially. }\end{array}$ \\
\hline Owner & GWSI & The owner of the well in the GWSI data base. \\
\hline Purveyor name & BSDW & $\begin{array}{l}\text { The owner or purveyor of a public-water-supply system in tl } \\
\text { BSDW data base. }\end{array}$ \\
\hline Local identifier - GWSI & GWSI & $\begin{array}{l}\text { The local name by which the well is known in the GWSI data } \\
\text { base. }\end{array}$ \\
\hline Local identifier - BSDW & BSDW & $\begin{array}{l}\text { The local name by which the well is known in the BSDW data } \\
\text { base. }\end{array}$ \\
\hline Aquifer code & GWSI & $\begin{array}{l}\text { Eight-character abbreviation that represents the aquifer or } \\
\text { hydrogeologic unit from which the well withdraws water. Aqui- } \\
\text { fer codes are given in tables } 1 \text { and } 2 \text {. }\end{array}$ \\
\hline Aquifer type & GWSI & $\begin{array}{l}\text { One-character code that represents the type of aquifer from } \\
\text { which the well withdraws water. }\end{array}$ \\
\hline Sensitivity rating & Determined & $\begin{array}{l}\text { Single-character code that represents whether the well is senci- } \\
\text { tive to contaminants from the land surface, based on confine- } \\
\text { ment near the well. }\end{array}$ \\
\hline Well type & BSDW & Single-digit code that represents the type of water-supply well. \\
\hline Well status & BSDW & $\begin{array}{l}\text { Single-character code assigned by BSDW that represents the } \\
\text { well's operational status. }\end{array}$ \\
\hline Use of well & $\begin{array}{l}\text { GWSI, BWA, } \\
\text { BSDW, NJGS }\end{array}$ & $\begin{array}{l}\text { Two-digit code that represents whether the well is sealed, } \\
\text { capped, or abandoned, and the source of this information. }\end{array}$ \\
\hline Use of water & GWSI & $\begin{array}{l}\text { One-character code that represents the primary use of water } \\
\text { from the well. }\end{array}$ \\
\hline
\end{tabular}


Table 2. Items stored in the water-supply-well data base for New Jersey, sources of data, and descriptions of items--Continued

\begin{tabular}{|c|c|c|}
\hline Data-base item & $\begin{array}{c}\text { Source(s) of } \\
\text { data }\end{array}$ & Description of item \\
\hline \multicolumn{3}{|c|}{ Purveyor address and contact information } \\
\hline Street & BWA, BSDW & Street address of the owner or purveyor. \\
\hline City & BWA, BSDW & City of the owner or purveyor. \\
\hline State & BWA, BSDW & State of the owner or purveyor. \\
\hline Zip code & BWA, BSDW & Zip code of the owner or purveyor. \\
\hline Purveyor contact & BWA, BSDW & Owner or purveyor representative. \\
\hline Purveyor phone number & BWA, BSDW & Phone number of the owner or purveyor representative. \\
\hline \multicolumn{3}{|c|}{ Well-construction information } \\
\hline Well depth & GWSI & The maximum depth of the well, in feet below land surface. \\
\hline Top of open interval & GWSI & $\begin{array}{l}\text { Depth of the top of the well screen or open interval, in feet } \\
\text { below land surface. }\end{array}$ \\
\hline Bottom of open interval & GWSI & $\begin{array}{l}\text { Depth of the bottom of the well screen or open interval, in feet } \\
\text { below land surface. }\end{array}$ \\
\hline Top of casing & GWSI & Depth of the top of the well casing, in feet below land surface. \\
\hline Bottom of casing & GWSI, BWA & $\begin{array}{l}\text { Depth of the bottom of the well casing, in feet below land } \\
\text { surface. }\end{array}$ \\
\hline Casing diameter & GWSI, BWA & Diameter of the inner casing, screen, or borehole, in inches. \\
\hline Type of open interval & GWSI & The type of opening that allows water to enter the well. \\
\hline Number of openings & GWSI & The number of screened or open intervals of the well. \\
\hline Date completed & GWSI & The construction-completion date of the well. \\
\hline Pumping capacity & $\begin{array}{l}\text { BWA, GWSI, } \\
\text { BSDW }\end{array}$ & The pumping capacity of the well, in gallons per minute. \\
\hline Capacity source & & The agency that provided the well pumping-capacity data. \\
\hline \multicolumn{3}{|c|}{ Well-location information } \\
\hline Latitude & $\begin{array}{l}\text { GWSI, BWA } \\
\text { BSDW }\end{array}$ & $\begin{array}{l}\text { Number that represents the latitude of the well's location, in } \\
\text { degrees, minutes, and seconds. }\end{array}$ \\
\hline Longitude & $\begin{array}{l}\text { GWSI, BWA, } \\
\text { BSDW }\end{array}$ & $\begin{array}{l}\text { Number that represents the longitude of the well's location, in } \\
\text { degrees, minutes, and seconds. }\end{array}$ \\
\hline Latitude longitude accuracy & GWSI & $\begin{array}{l}\text { One-character code that represents the accuracy of the latitude } \\
\text { and longitude measurement. }\end{array}$ \\
\hline Grid number & GWSI & $\begin{array}{l}\text { Number assigned by BWA that represents the grid location of } \\
\text { the well on the State Atlas Maps. }\end{array}$ \\
\hline Altitude & GWSI & Altitude of land surface at the well, in feet above sea level. \\
\hline Altitude method & GWSI & $\begin{array}{l}\text { One-character code that represents the method by which the } \\
\text { altitude was measured. }\end{array}$ \\
\hline Altitude accuracy & GWSI & $\begin{array}{l}\text { Number that represents the accuracy of the altitude measure- } \\
\text { ment. }\end{array}$ \\
\hline County & GWSI & $\begin{array}{l}\text { Three-digit number that represents the county in which the well } \\
\text { is located. County codes are given in table } 1 \text {. }\end{array}$ \\
\hline Township & GWSI & Township in which the well is located. \\
\hline Map name & GWSI & $\begin{array}{l}\text { Name of USGS } 7.5 \text {-minute quadrangle map in which the well is } \\
\text { located. }\end{array}$ \\
\hline
\end{tabular}


Table 3. Items added to the water-supply-well data base by the New Jersey Geological Survey [USGS, U.S. Geological Survey; NAD 83, North American Datum of 1983]

Data-base item

Easting

Northing

FIPS number

Quad number

Water use code

Well status code

Locational method

Total casing length

Geologic formation code

Transmissivity

Aquifer thickness

Aquifer porosity

Hydraulic gradient

Azimuth

Pumping rate

CFR 1 radius

CFR 2 radius

Date delineated

Person performing delineation

Comments

\section{Description of item}

Number that represents the $x$ coordinate of the well location. Value is in U.S. Survey feet, in NAD 83 of State Plane Coordinate System.

Number that represents the y coordinate of the well location. Value is in U.S. Survey feet, in NAD 83 of State Plane Coordinate System.

Number that represents the county and municipality in which the well is located. First two digits represent the county; last three represent the municipality.

Three-digit code that represents the USGS 7.5-minute quadrangle in which the well is located.

Two-digit code that represents the primary use of water from the well.

One-digit code that represents the operational status of the well.

One-character code that represents the method used to determine the location of the well.

Total length of casing installed in the well, in feet.

Four-character code that represents the name of the primary geologic formation penetrated by the well.

Hydraulic conductivity of the aquifer multiplied by the well's open-interval length, in feet squared per day.

Length of the screen or open interval of the well, in feet.

Effective porosity of the aquifer penetrated by the well (dimensionless).

Change in hydraulic head per unit distance in the direction of maximum change (dimensionless).

Measure of direction in which ground water flows, in degrees.

Maximum pumping capacity of the installed pump, in cubic feet per day.

Radius of a 200-day time of travel from the well, in feet, determined by using the Calculated Fixed Radius equation (N. J. Department of Environmental Protection and Energy, 1991).

Radius of a 5-year time of travel from the well, in feet, determined by using the Calculated Fixed Radius equation (N. J. Department of Environmental Protection and Energy, 1991).

Date of generation of the wellhead-protection area.

Name of the person who generated the wellhead-protection area.

Comments regarding the well or wellhead-protection area. 
Table 3. Items added to the water-supply-w ell data base by the New Jersey Geological Survey-Continued

\section{Data-base item}

Lot

Block

Reference elevation

Elevation comment

Natural flow

Test date

Test type

Ground-water elevation

Static water level

Pumping water level

Drawdown

Test length

Discharge rate

Specific capacity

Drilling contractor

License number

Drilling method code

Driller's log

Geologist

Geologist's log

Geophysical log

Lithologic log

Samples

Water quality

Water level

Fossils

\section{Description of item}

Lot designation of the property on which the well is located.

Block designation of the property on which the well is located.

Elevation of the well's measuring point, in feet above sea level.

Comments or additional information about the reference elevation of the well.

Rate of flow from the well without pumping, in gallons per minute.

Date of tests of the well, listed on the well record.

Type of test conducted.

Elevation of ground water measured in the well, in feet above sea level.

Depth to water in the well prior to pumping, in feet below land surface.

Depth to water in the well during pumping, in feet below land surface.

Drop in water level in the well during an aquifer test, in feet.

Duration of the aquifer test, in minutes.

Rate of discharge during the aquifer test, in gallons per minute.

Discharge rate divided by drawdown, in gallons per minute per foot.

Name of the well-drilling contractor who installed the well.

The State license number of the drilling contractor.

One-character code that represents the method used to install the well.

Driller's $\log$ of the installation of the well.

Geologist who reviewed or supervised the installation of the well.

Geologist's log of the well.

One-character code that indicates whether geophysical logs are available.

One-character code that indicates whether lithologic logs are available.

One-character code that indicates whether geologic samples are available.

One-character code that indicates whether water-quality data are available.

One-character code that indicates whether water-level data are available.

One-character code that indicates whether fossils were present in geologic samples. 


\section{METHOD TO EVALUATE THE SENSITIVITY OF WELLS TO CONTAMINATION}

All wells for which information was sufficient were evaluated for their sensitivity to contaminants generated at land surface. Wells were considered to be sensitive if recharge moving along any flow path from the land surface would reach the well in less than 12 years. The minimum data required to make this determination include depth of the open interval, location of the well, and altitude of the top of the well. Wells in aquifers that are considered to be confined to the degree that contamination from land surface is unlikely to reach the well opening are exemvt from wellhead-protection-area delineation regulations (N.J. Department of Environmental Protection, 1991). A well is considered sufficiently confined (and thus insensitive to contamination) when the vertical time of travel through a confining unit and the horizontal time of travel to the edge of a confining unit is equal to or exceeds 12 years at all points. The method used to determine the sensitivity of wells had to be (1) simple to use--the method had to be applicable to all wells with a minimum of data and to provide results that are easy to understand--and (2) conservative, meaning that the method had to provide for a well to be considered insensitive to contamination if the minimum time of travel of recharge water to the well was greater than 12 years. A schematic diagram that depicts the method used to determine the sensitivity or insensitivity of community water-supply wells to contamination is shown in figure 3. A summary showing the number of wells in the data base that are sensitive to contamination, listed by county and by aquifer, is presented in table 4 for glacial and Coastal Plain aquifers and in table 5 for bedrock aquifers.

Hydrogeologic variables that were used to assess sensitivity of wells to contamination from land surface include the depth to the top of the open interval below land surface, the presence or absence of confining units above the well's open interval, and the location of the well relative to the outcrop area of the aquifer penetrated by the well. Results of previous investigations of confined aquifers have shown that the distance of a well from the aquifer's outcrop area is the best predictor of contamination in the well (Vowinkel and Battaglin, 1989). Other variables. such as soil type, depth to water, recharge to the aquifer system, and ground-water withdrawals, were not used for this assessment because their effect on ground-water travel time is small compared to that of the three variables that were used. Results of previous investigations have shown that soil type is not significantly related to nitrate concentrations in ground water (Vowinkel and others, 1994). Recharge to surficial aquifers and the depth to water in aquifers in New Jersey does not vary significantly; the depth to water in wells open to unconfined aquifers in New Jersey typically is less than $25 \mathrm{ft}$. For the purposes of this report, the travel time of recharge from the land surface to the water table is assumed to be negligible.

Well-construction characteristics can significantly affect a well's sensitivity to contamiration. Boxplots comparing well depth, depth to the top of the open interval, and length of the open interval for wells in glacial, Coastal Plain, and bedrock aquifers are shown in figure 4 . Wells in glacial aquifers generally are constructed with short casing lengths and screens; well depths and depths to the top of the open interval are very shallow. Wells in bedrock aquifers typically are constructed with short casing lengths through the unconsolidated zone above the bedrock and long open boreholes through the bedrock that commonly exceed several hundred feet in length. Open intervals typically pass through many fracture zones to allow sufficient water to enter the 


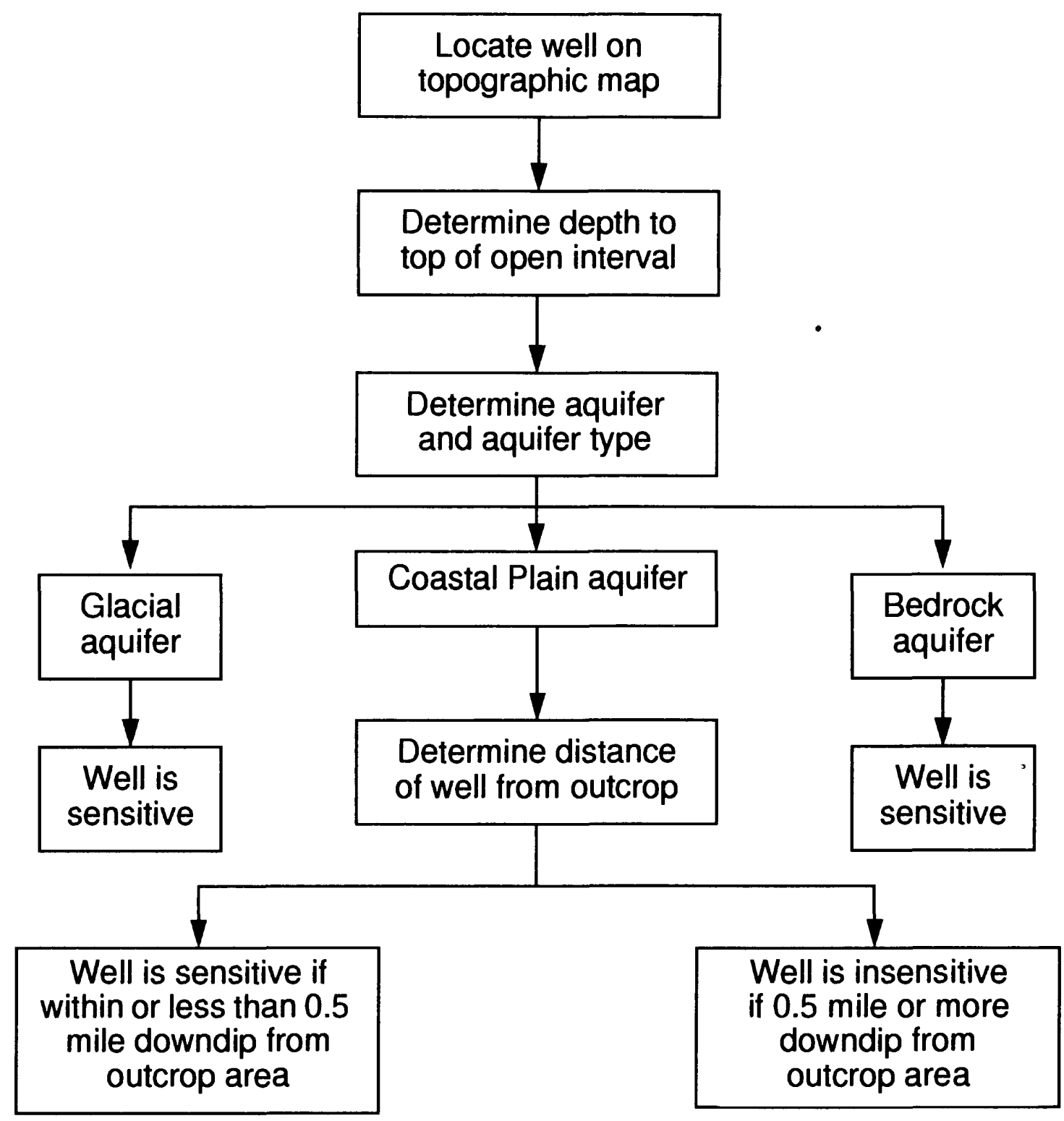

Figure 3. Method used to determine sensitivity of community water-supply wells in New Jersey to contamination from land surface. 
Table 4. Number of wells in glacial and Coastal Plain aquifers in New Jersey in the water-supply-well data base, ard number of wells that are sensitive to contamination, by county and by aquifer

[-, no wells in this aquifer in this county; stratigraphic and hydrogeologic characteristics of geologic units are shown in table 5]

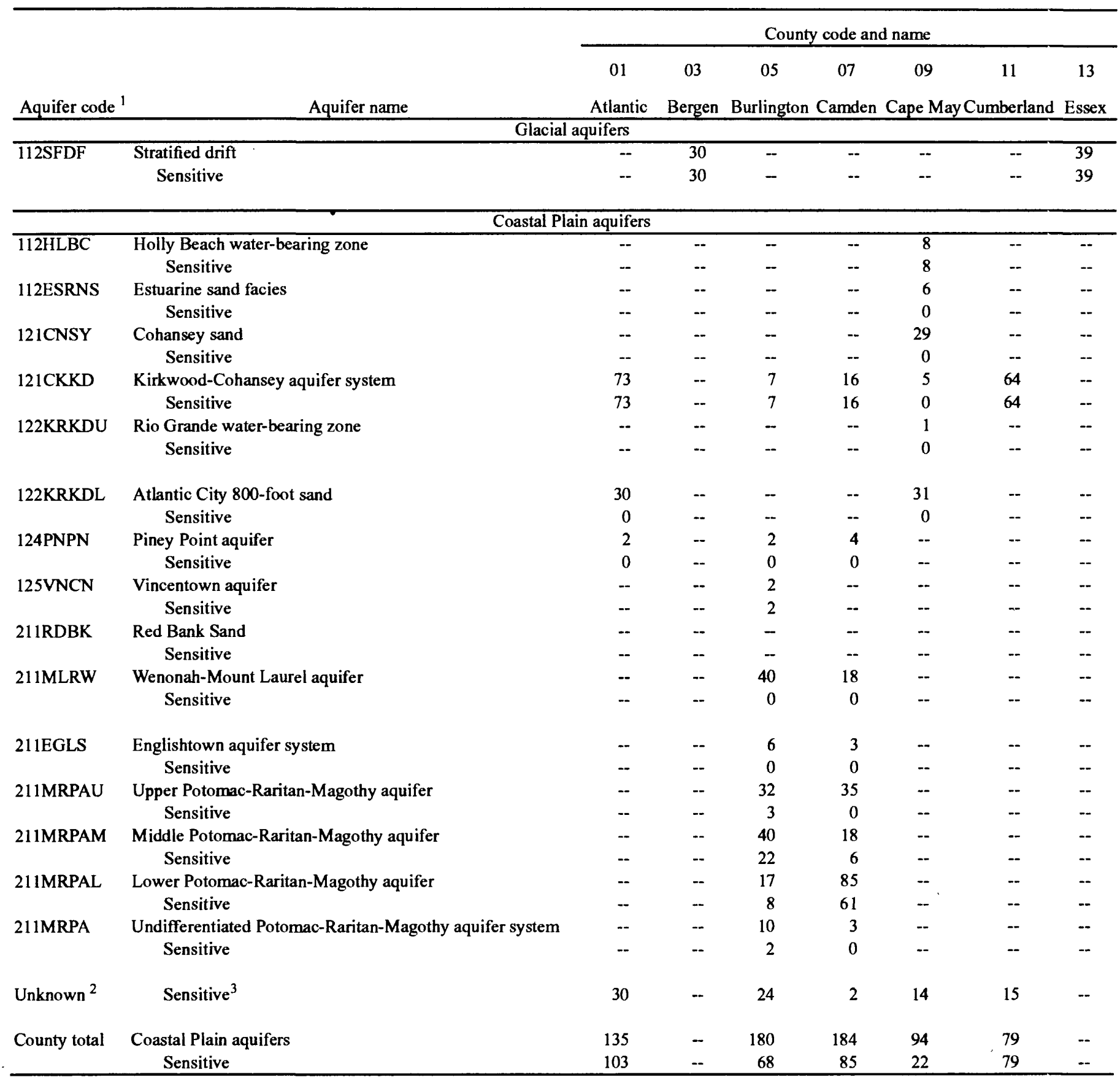

${ }^{1}$ The first three numbers of the aquifer code represent the geologic age of the aquifer; the last four to five characters are ar abbreviation of the aquifer name.

${ }^{2}$ Includes wells for which location of well, open interval, or well depth is unknown, or well is no longer used as communit.' watersupply well. The sensitivity could not be determined due to insufficient information.

${ }^{3}$ All wells whose aquifer code is unknown are assumed to be sensitive to contamination. 
Table 4. Number of wells in glacial and Coastal Plain aquifers in New Jersey in the water-supply-well data base, ar t number of wells that are sensitive to contamination, by county and by aquifer-Continued

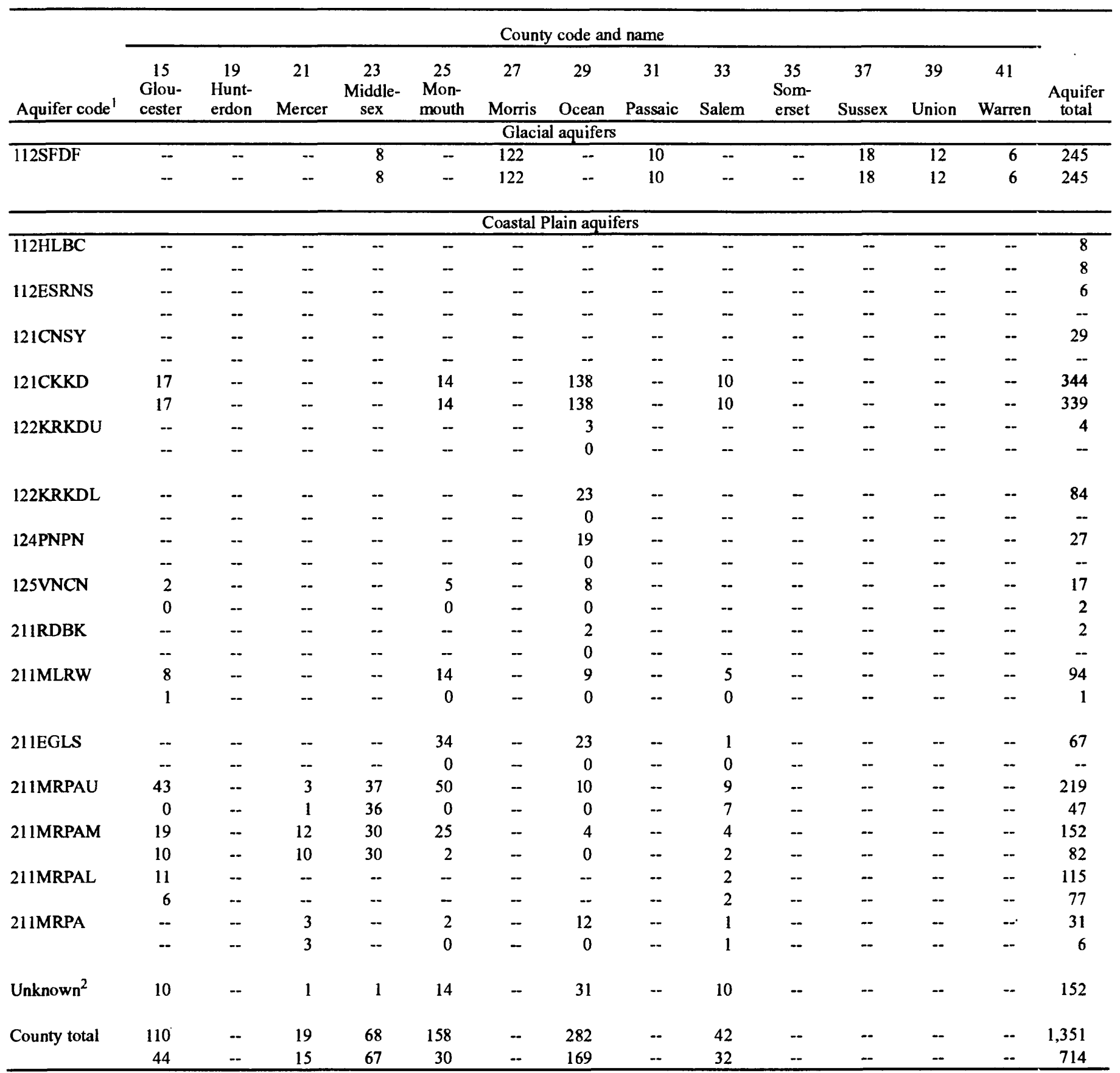


Table 5. Number of wells in bedrock aquifers in New Jersey in the water-supply-well data base, by county and by aquifer

[--, no wells in this aquifer in this county; stratigraphic and hydrogeologic characteristics of geologic units are shown in tab'e 5; all wells in bedrock aquifers are considered to be sensitive to contamination from land surface]

\begin{tabular}{|c|c|c|c|c|c|c|c|c|}
\hline \multirow[b]{2}{*}{ Aquifer code ${ }^{1}$} & \multirow[b]{2}{*}{ Aquifer name } & \multicolumn{7}{|c|}{ County code and name } \\
\hline & & $\begin{array}{c}01 \\
\text { Atlantic } \\
\end{array}$ & $\begin{array}{c}03 \\
\text { Bergen } \\
\end{array}$ & $\begin{array}{c}05 \\
\text { Burlington } \\
\end{array}$ & $\begin{array}{c}07 \\
\text { Camden } \\
\end{array}$ & $\begin{array}{c}09 \\
\text { Cape May } \\
\end{array}$ & $\begin{array}{c}11 \\
\text { Cumberland } \\
\end{array}$ & $\begin{array}{c}13 \\
\text { Essex } \\
\end{array}$ \\
\hline 227BRCKS & Brunswick Group Sedimentary (undifferentiated) & -- & 28 & - & - & -- & -- & 22 \\
\hline 227BNTN & Boonton Formation & - & -- & -- & - & - & - & 2 \\
\hline $227 \mathrm{HKMN}$ & Hook Mountain Basalt & - & -- & - & - & -- & -- & 1 \\
\hline 227TOWC & Towaco Formation & -- & -- & -- & - & -- & - & 5 \\
\hline 227PRKS & Preakness Basalt & $\because$ & -- & -- & - & -- & - & 5 \\
\hline 227FLVL & Feltville Formation & -- & -- & -- & - & -- & -- & 2 \\
\hline 227PSSC & Passaic Formation & -- & 139 & -- & - & -- & -- & 25 \\
\hline 227BSLT & Basalt & -- & -- & -- & - & -- & -- & 4 \\
\hline 231CGLMU & Unclassified conglomerate & -- & - & -- & - & -- & -- & -- \\
\hline 230TRSC & Triassic System & -- & -- & - & - & - & - & -- \\
\hline 231LCKG & Lockatong Formation & -- & - & -- & - & -- & -- & -- \\
\hline 231QRCG & Quartzite conglomerate & -- & - & -- & - & -- & -- & - \\
\hline $231 S C K N$ & Stockton Formation & -- & -- & - & - & -- & -- & -- \\
\hline 341SKMK & Skunnemunk Conglomerate & -- & - & -- & - & -- & - & - \\
\hline 344BLVL & Bellvale Sandstone & -- & - & - & - & -- & -- & -- \\
\hline 344CRNL & Cornwall Shale & -- & -- & -- & - & -- & -- & -- \\
\hline 344ESPS & Esopus Formation & -- & -- & - & - & -- & -- & -- \\
\hline 344KNUS & Kanouse Sandstone & -- & -- & - & - & -- & -- & -- \\
\hline 350GRPD & Green Pond Conglomerate & -- & -- & -- & - & -- & -- & - \\
\hline 350HGFL & High Falls Formation (Bloomsburg Formation) & -- & - & -- & - & - & - & - \\
\hline 351BDVL & Bossardville Limestone & - & -- & -- & - & -- & -- & -- \\
\hline 351DCKR & Decker Formation & - & -- & -- & - & -- & - & -- \\
\hline 360KTTN & Kittatinny Supergroup (undifferentiated) & -- & -- & -- & - & -- & -- & - \\
\hline $3600 D V C$ & Ordovician System & -- & -- & - & - & -- & -- & -- \\
\hline 361BSKL & Bushkill Member of Martinsburg Shale & -- & -- & -- & - & - & -- & - \\
\hline $361 \mathrm{MRBG}$ & Martinsburg Shale & -- & -- & -- & - & -- & -- & -- \\
\hline 364JKBG & Jacksonburg Limestone & -- & - & -- & - & -- & -- & -- \\
\hline 367EPLR & Epler Formation & -- & -- & - & - & -- & -- & -- \\
\hline 367RCKB & Rickenbach Dolomite & -- & -- & -- & - & -- & -- & -- \\
\hline 371ALNN & Allentown Dolomite & -- & -- & -- & - & - & -- & - \\
\hline 374LSVL & Leithsville Fomation & - & -- & $-\cdot$ & - & -- & -- & -- \\
\hline 377HRDS & Hardyston Quartzite & - & -- & -- & - & - & -- & - \\
\hline 400FRKL & Franklin Limestone & -- & -- & -- & - & - & -- & -- \\
\hline 400РCMB & Precambrian Erathem (Proterozoic) & -- & -- & -- & - & -- & -- & -- \\
\hline Unknown $^{2}$ & & - & 15 & - & - & -- & - & 7 \\
\hline County total & & - & 182 & -- & - & - & - & 73 \\
\hline
\end{tabular}

${ }^{1}$ The first three numbers of the aquifer code represent the geologic age of the aquifer; the last four to five characters are an abbreviation of the aquifer name.

${ }^{2}$ Includes wells for which location of well, open interval, or well depth is unknown, or well is no longer used as community watersupply well. 
Table 5. Number of wells in bedrock aquifers in New Jersey in the water-supply-well data base, by county and by aquifer-Continued

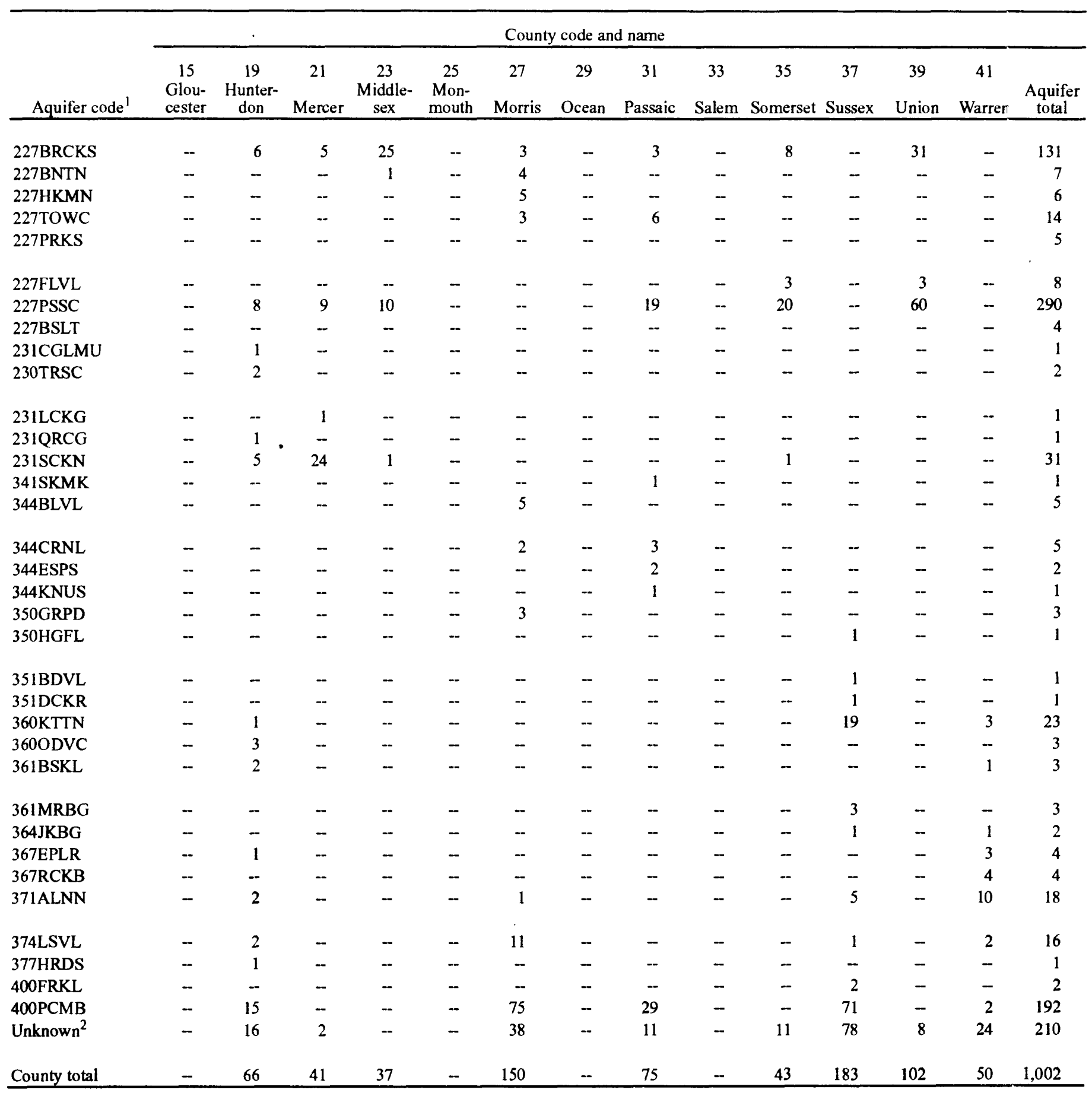


(A) WEL DEPTH

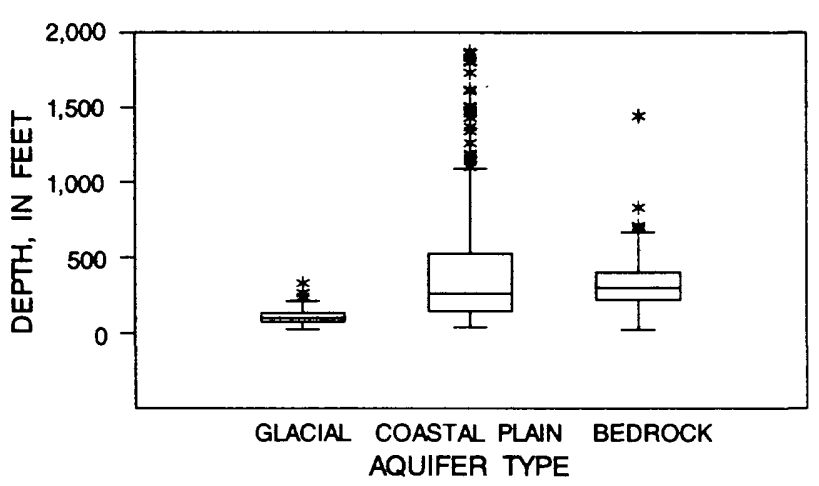

(C) LENGTH OF OPEN INTERVAL

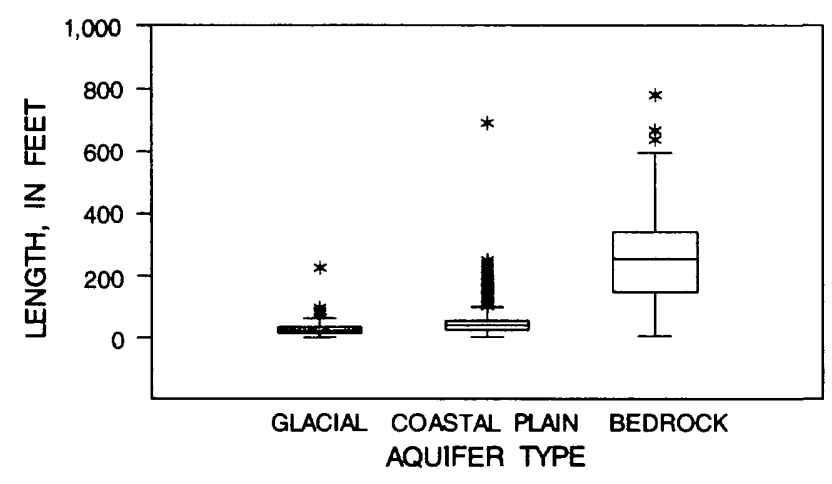

(B) TOP OF OPEN INTERVAL

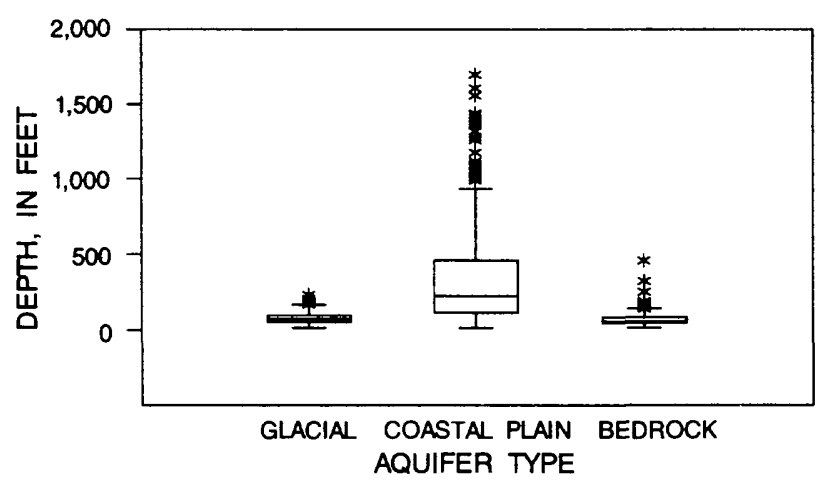

EXPLANATION

* OUTUER

UPPER WHISKER--The larger data value greate -

than or equal to the upper quartile plus 1.5

times the interquartile range

75th PERCENTLE

MEDIAN

25th PERCENTLE

LOWER WHISKER--The smallest data value less than or equal to the lower quartile minus 1.5 times the interquartile range

Figure 4. Distributions of well depth, depth to the top of the open interval, and length of the open interval for wells in glacial, Coastal Plain, and bedrock aquifers, New Jersey. 
well. Wells in bedrock aquifers typically have the longest open intervals by far as well as the shallowest depth to the top of the open interval. Wells in Coastal Plain aquifers generally are constructed with long casing lengths and short screens in the unconsolidated sediments, although well depths and depths to the top of the open interval can vary significantly.

Confinement that protects wells from contaminants discharged at land surface is linked to thick, areally extensive, impermeable units, which are common in the Coastal Plain but rarely are found in glacial and bedrock aquifers in New Jersey. Confining units restrict the vertical and horizontal movement of ground water and reduce contaminant concentrations by processes of diffusion, adsorption, and biodegradation. (Reports documenting the location, extent, and thickness of such confining units in glacial and bedrock aquifers are rare.) Thin confining units of fine-grained sediments are probably present in most valleys in New Jersey; however, most confining units in glacial sediments probably are leaky so that travel times from the land surface to the well are small. For the purposes of this study, therefore, all wells with open intervals in glacial and bedrock aquifers are considered to be sensitive to contaminants discharged at land surface because no thick, areally extensive confining units have been documented in these aquife* types in New Jersey.

The concentration of tritium in ground-water samples can be used to indirectly assess the sensitivity of a well to contamination discharged at land surface by providing an indication of the length of time since the ground water was exposed to the atmosphere (Hendry, 1988). Although they were not directly used in this study to evaluate the sensitivity of community water-supply wells, tritium-concentration data can be used to (1) verify that the minimum time of travel is far greater than 12 years or (2) indicate that other methods are needed to accurately determine the minimum travel time.

Above-ground thermonuclear testing has caused large amounts of tritium to be injected into the atmosphere. Ground-water samples that contain high concentrations of tritium indicate that at least some of the water was deposited as precipitation after 1952, when atmospheric nuclear testing began. Samples that contain less than $0.64 \mathrm{pCi} / \mathrm{L}$ tritium indicate that the water was exposed to the atmosphere before 1952, when natural tritium concentrations were low (Hendry, 1988), and indicate that the likelihood that contaminants will enter the well within a 12year period is small. Samples that contain more than $0.64 \mathrm{pCi} / \mathrm{L}$ tritium do not necessarily indicate that the well is sensitive to contamination, but that some of the water from the well was recharged from precipitation since 1952. Figure 5 shows boxplots of tritium concentrations in water samples from wells with open intervals in glacial aquifers, the Kirkwood-Cohansey aquifer system (an unconfined Coastal Plain aquifer system), and bedrock aquifers. The KirkwoodCohansey aquifer system is assumed to contain relatively young water because it is not overlain by any extensive confining units. Tritium concentrations in most samples from all three aquifer types are high, indicating that the water recharged the aquifers after 1952.

\section{Glacial Aquifers}

Wisconsinan glacial-drift material is present in the northern part of the Valley and Ridge, Highlands, and Piedmont Physiographic Provinces, generally occupying the valley areas (fig. 6). These nonmarine sediments comprise a discontinuous veneer that forms the floor of the northeast- 


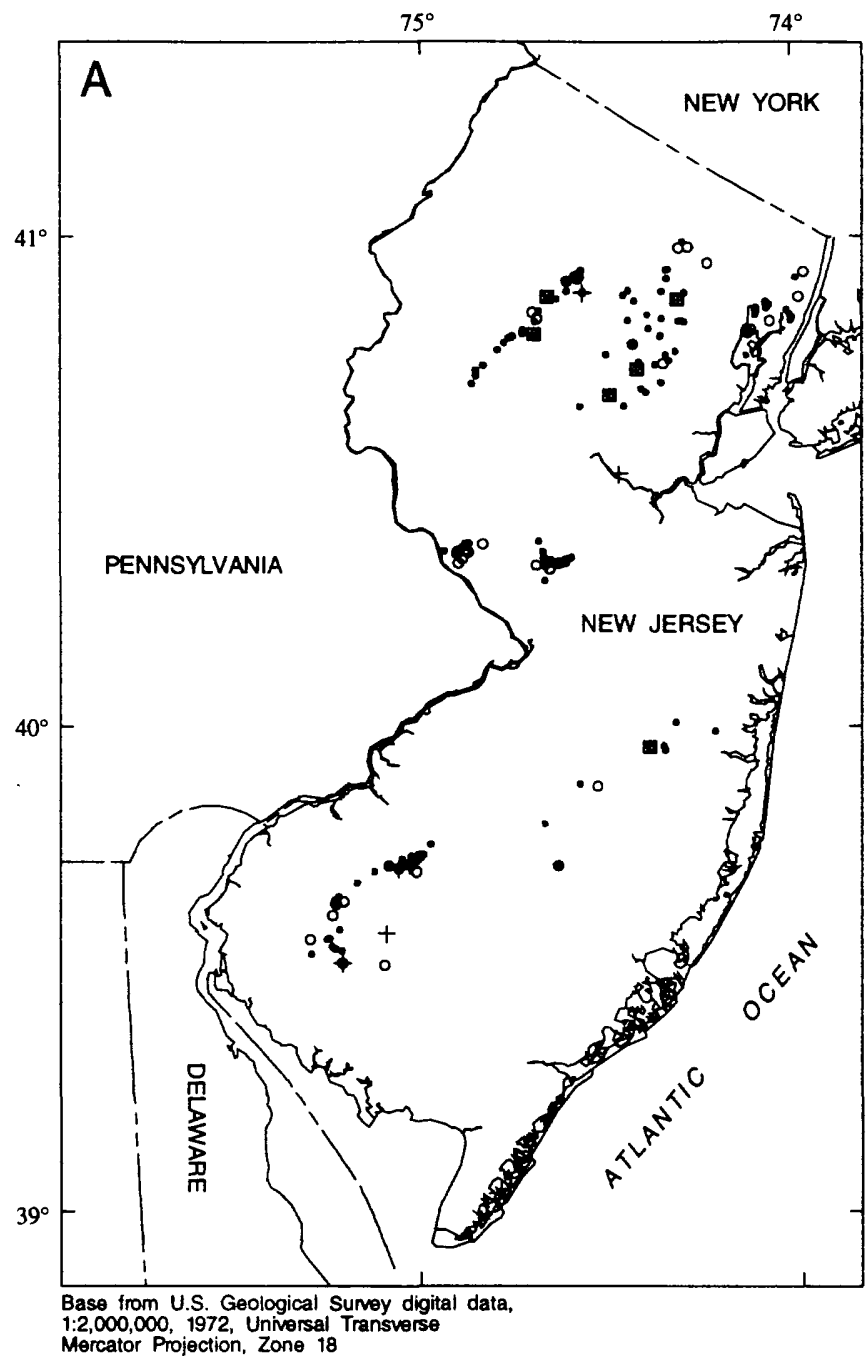

EXPLANATION

TRITIUM CONCENTRATION, IN PICOCURIES PER UTER

+ Less than 5.0

a 5.0 to 24.9

- 25.0 to 49.9

- 50.0 or greater

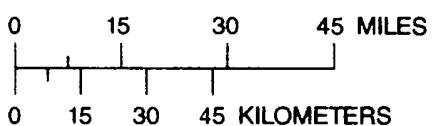

EXPLANATION
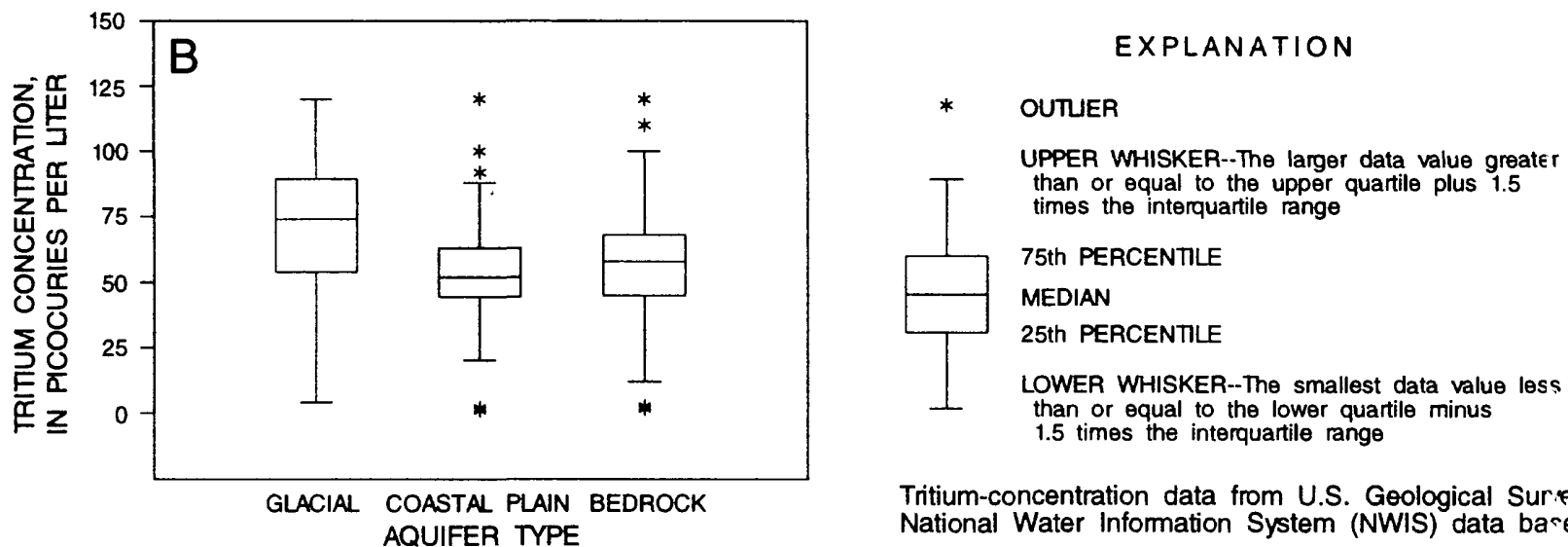

Tritium-concentration data from U.S. Geological Surey National Water Information System (NWIS) data bare

Figure 5. (A) Distribution of tritium concentrations in water samples from sampled wells, and (B) distributions of tritum concentrations in water samples from wells with open intervals in glacial aquifers, the Kirkwood-Cohansey aquifer system, and bedrock aquifers. 
southwest-trending valleys between ridges of resistant bedrock. The glacial drift varies in thickness and lateral extent. Stratified sediments, which include lakebottom, fluvial, deltaic, and lacustrine deposits, consist of clay, silt, sand, and gravel that can be greater than $200 \mathrm{ft}$ thick. Bedrock ridges commonly are overlain by discontinuous till deposits that generally are less than $20 \mathrm{ft}$ thick. The terminal moraine trends northwest-southeast across the central part of the three provinces (fig. 6). Moraine deposits generally are present as ridges and knolls along former ice margins and can be as much as $200 \mathrm{ft}$ thick. The materials comprising these deposits consist of poorly sorted sand, gravel, and boulders with interbedded silt and clay lenses (Stanford and others, 1990). A generalized cross-section showing aquifer and confining-unit geometry and ground-water flow patterns in this type of aquifer is shown in figure 7.

Two distinct types of aquifer systems--glacial and bedrock--are found in the Piedmont, Highlands, and Valley and Ridge Physiographic Provinces (fig. 1). Glacial drift in the scoured valleys is a source of abundant ground water in the northern half of New Jersey. Many community water-supply wells are completed in glacial sediment because yields from these wells typically are greater than those from wells in the surrounding bedrock aquifers. Water in glacial aquifer systems, like water in the Coastal Plain, typically enters a well from pore spaces in the aquifer material surrounding the well opening. Recharge to glacial aquifers typically enters the system as direct infiltration of precipitation and seepage from surface-water bodies through the valley floor and, near the base of the valley walls, of overland runoff from upland areas, because infiltration into the competent bedrock there is small as a result of low porosity (Risser and Madden, 1994).

Wells screened in glacial aquifer systems typically are less than $150 \mathrm{ft}$ deep because glacial sediments are relatively thin. The depth to the top of the open interval of wells in glacial aquifers is commonly less than $100 \mathrm{ft}$ below land surface (fig. 4). These wells typically have short open intervals because yields in glacial aquifers tend to be large. Median values determined from wells in the water-supply-well data base of the depth to the top of the open interval and the well depth for wells in stratified drift are 78 and $102 \mathrm{ft}$ below land surface, respectively.

An available ground-water flow model was used to estimate the time of travel to, and evaluate the sensitivity to contamination of, selected wells in a "typical" glacial-aquifer setting. The contributing areas of three wells $(27-82,27-83$, and 27-86) located in the Highlands Physiographic Province in a glacial aquifer are shown in figure 8 . The contributing areas were delineated by use of a numerical ground-water flow model with a particle-tracking analysis to simulate flow paths and determine time of travel (D.E. Rice and L.M. Voronin, U.S. Geological Survey, written commun., 1995). Ground-water contributing areas associated with travel times less than or equal to 12 years are distinguished from those associated with travel times greater than 12 years. These wells were selected for this analysis because they represent a variety of conditions that are typical in glacial-valley aquifer systems in New Jersey. Selected well-construction and time-of-travel data for these wells are presented in table 6.

Picatinny Arsenal well 130 (27-82) is screened from 102 to $117 \mathrm{ft}$ below land surface in stratified drift that is locally confined. Simulation results indicate that travel times from the water table to the well generally are less than 12 years. The well's contributing area is near the base of 

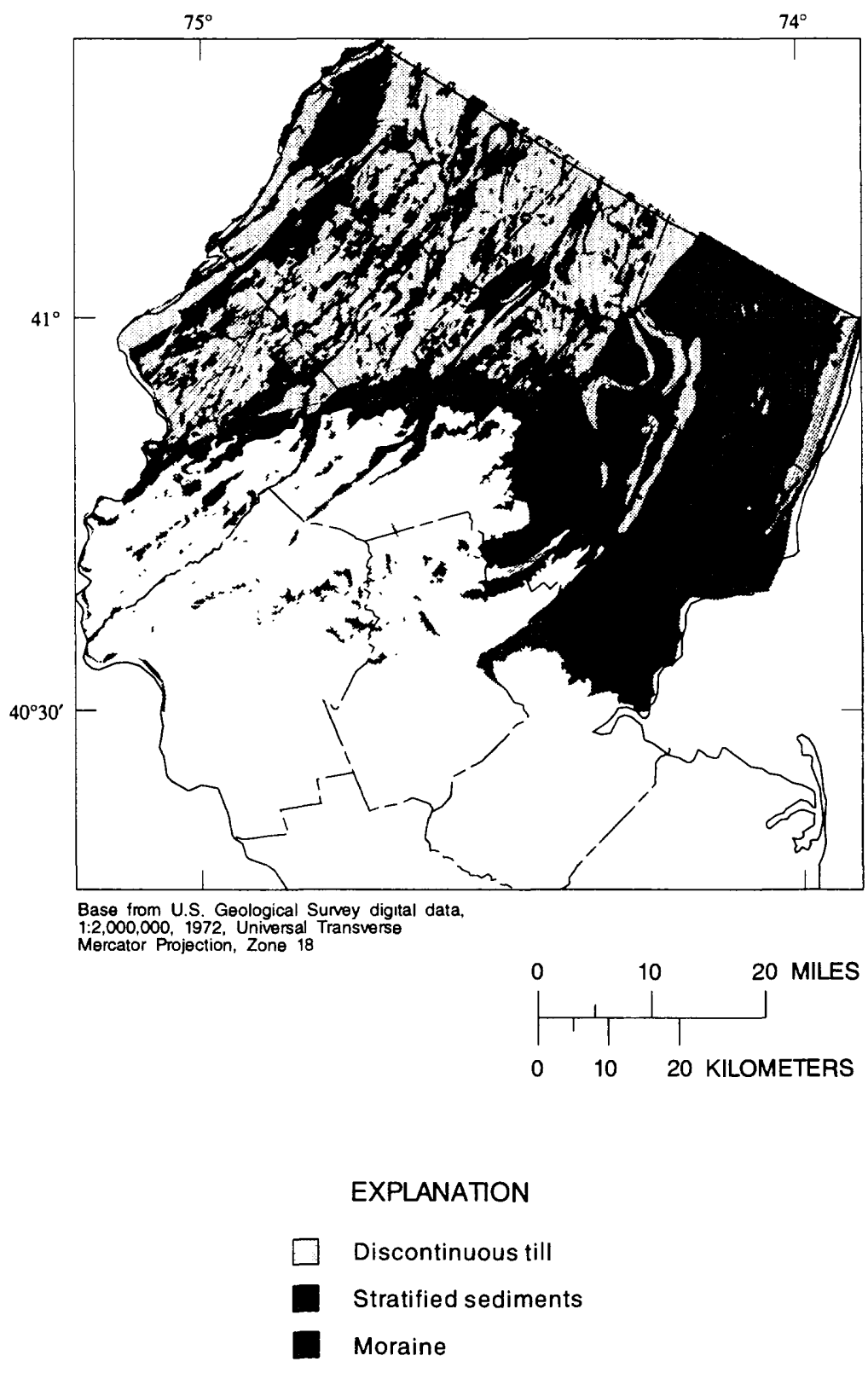

Figure 6. Extent of glacial sediments in northern New Jersey. (Modified from Stanford and others, 1990.) 


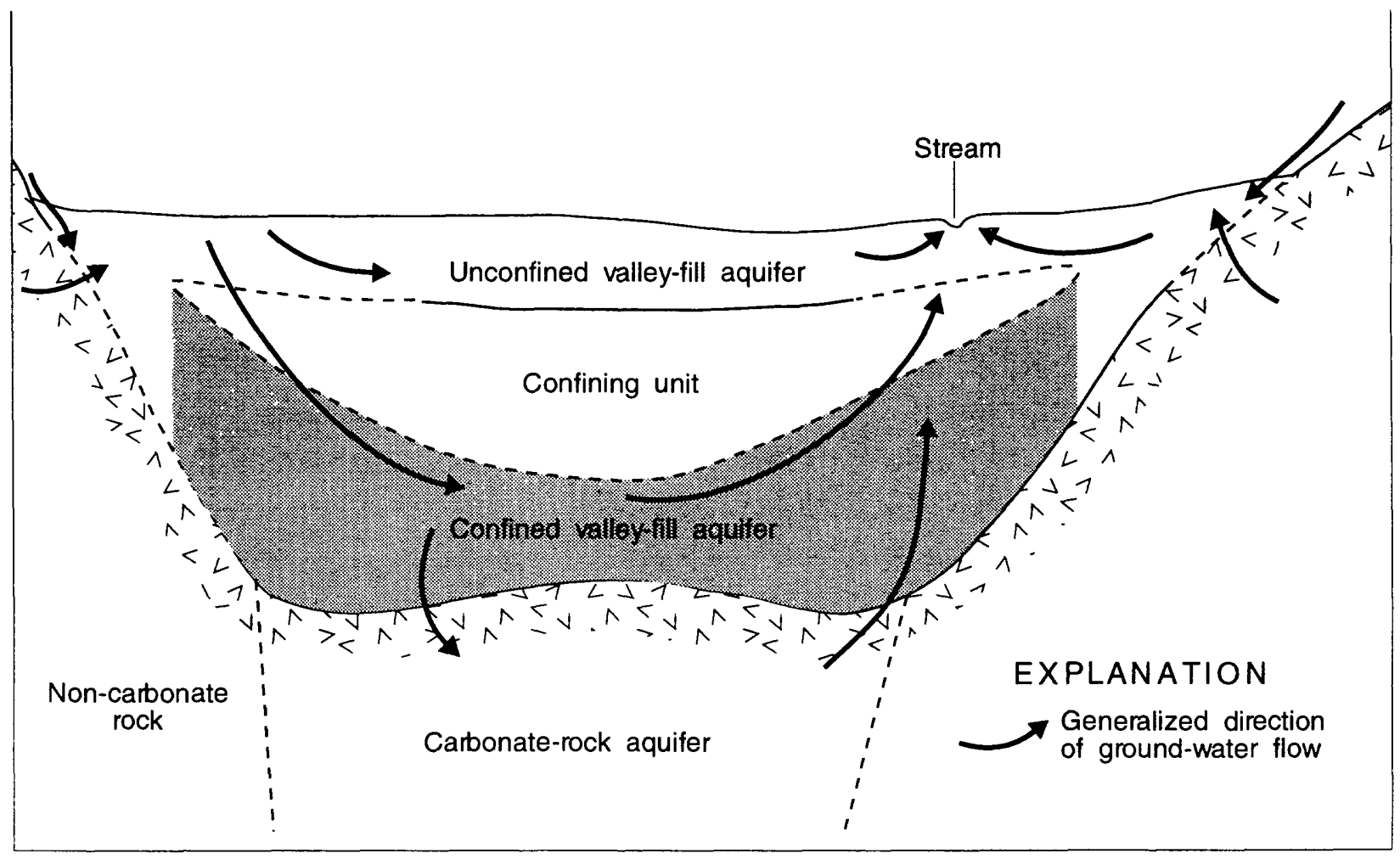

NOT TO SCALE

Figure 7. Generalized hydrogeologic section showing aquifer and confining-unit geometry and ground-water flow paths in glacial aquifers in northern New Jersey. (Modified from Sargent and others, 1990.) 


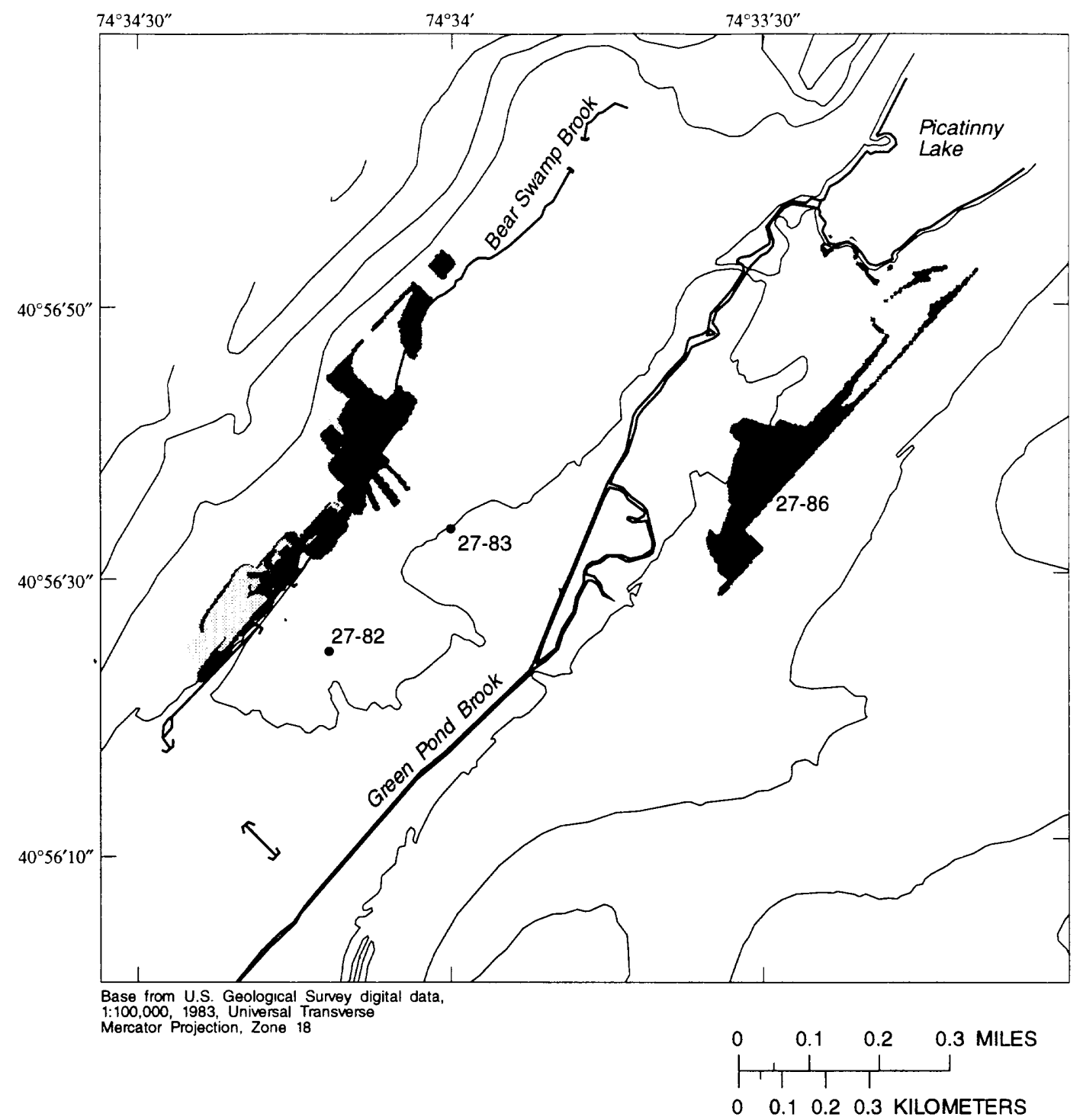

EXPLANATION

TIME OF TRAVEL, IN YEARS

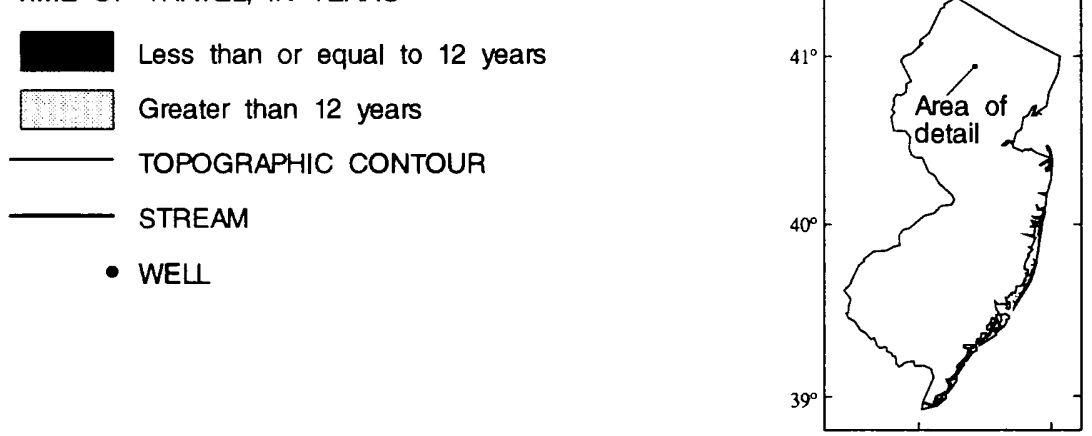

Figure 8. Simulated ground-water contributing areas and travel times for wells 27-82, 27-83, and 27-86 in a glacial aquifer at Picatinny Arsenal, Morris County, New Jersey. (Modified from DE. Rice and LM. Voronin, US. Geological Survey, written commun., 1995.) 
Table 6. Selected well-construction data and simulated ground-water travel times for community water-supply wells screened in glacial and bedrock aquifers in Morris County, New Jersey

\begin{tabular}{ccccccc}
\hline \multirow{2}{*}{$\begin{array}{c}\text { Well } \\
\text { number }\end{array}$} & $\begin{array}{c}\text { Depth of open } \\
\text { interval, in feet } \\
\text { below land surface }\end{array}$ & Aquifer type & Hydrogenlogic characteristics & \multicolumn{3}{c}{ Travel time, in years } \\
\cline { 5 - 7 } $27-82$ & $102-117$ & Glacial & $\begin{array}{l}\text { About } 60 \text { feet of alternating } \\
\text { beds of very fine sand, silt, } \\
\text { and clay }\end{array}$ & 2 & 8 & 40 \\
$27-83$ & $110-403$ & $\begin{array}{l}\text { Glacial and } \\
\text { bedrock }\end{array}$ & $\begin{array}{l}\text { Screened partly in glacial } \\
\text { sediments and partly in bed- } \\
\text { rock. Minimal confining } \\
\text { material above open interval }\end{array}$ & 1 & 10 & 619 \\
$27-86$ & $75-85$ & Glacial & $\begin{array}{l}\text { Minimal confining material } \\
\text { above screened interval }\end{array}$ & 1 & 2.3 & 150 \\
\hline
\end{tabular}

the valley wall rather than around the well. Boxplots showing the distribution of simulated travel times are shown in figure 9. The median time of travel from the water table to the well is about 8 years. The minimum and maximum time of travel to well 130 are 2 and 40 years, respectively.

Well 410 (27-86) at Picatinny Arsenal also is completed in the glacial aquifer system (fig. 8). The well is screened from 75 to $85 \mathrm{ft}$ below land surface in stratified drift. Only minimal confining material is present above the screened interval. The contributing area is partly around the well and partly in an area upvalley near Picatinny Lake. Most recharge enters the aquifer system near the valley wall. The time of travel from the water table to the well for nearly all of the contributing area is less than or equal to 12 years; therefore, the well is considered to be sensitive to contaminants discharged at land surface. The median simulated time of travel is 2.3 years (fig. 9), with minimum and maximum times of 1 and 150 years, respectively (table 6). Because some of the water in this well originates near the valley wall and near Picatinny Lake, about 0.5 mi upvalley from the well, a wellhead-protection area around the well would not protect it from contaminants originating at land surface in these areas.

Well 302D (27-83) at Picatinny Arsenal is open to both the glacial aquifer and the underlying bedrock aquifer. This well's open interval extends from 110 to $403 \mathrm{ft}$ below land surface and only minimal confining material is present above the open interval. The contributing area (fig. 8) is near the base of the valley wall rather than around the well. The median simulated time of travel is 10 years; therefore, most of the recharge reaches the well in less than 12 years (fig. 9).

Ground-water flow in most glacial aquifer systems probably behaves similarly to that in the glacial aquifer system at Picatinny Arsenal. In this study, all wells with open intervals in glacial aquifers are considered to be sensitive to contamination discharged at land surface because of (1) the lack of mappable, extensive confining units; (2) the short travel times from land surface to the well; and (3) the typical construction characteristics of wells in glacial aquifers, which include shallow depth to the top of the open interval and shallow depth of the well. 


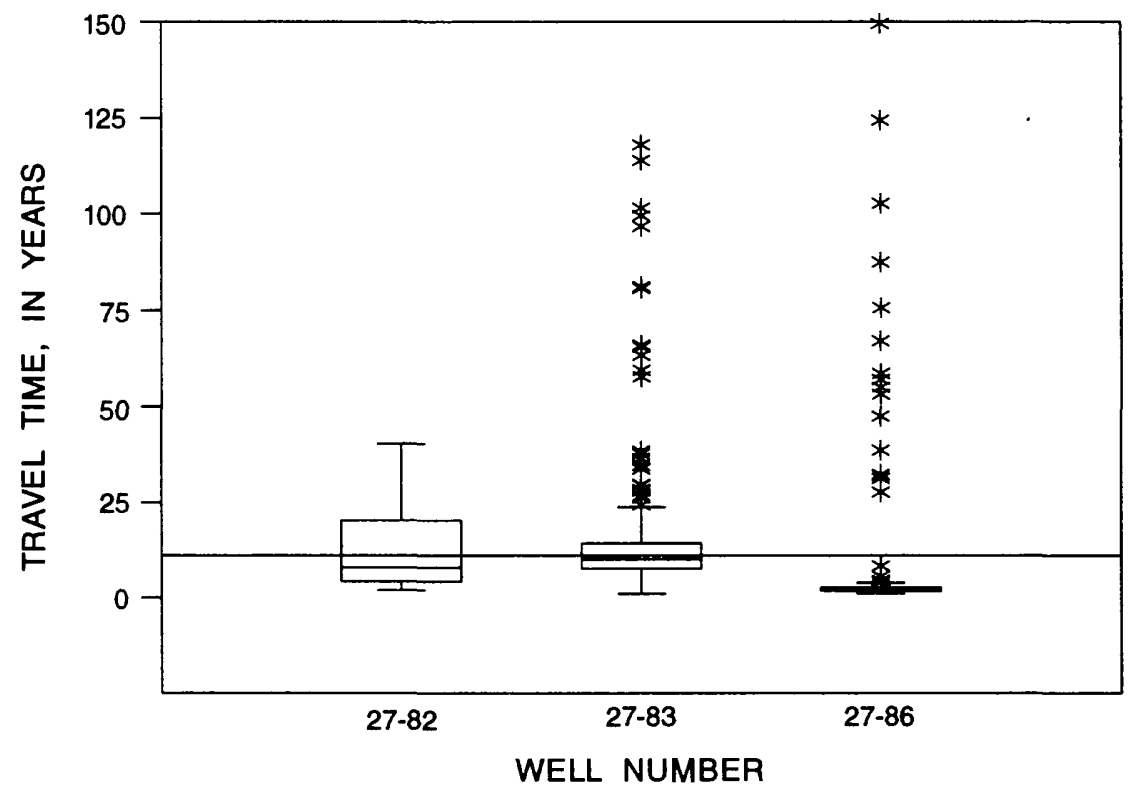

EXPLANATION

* outuer

UPPER WHISKER-The larger data value greater

than or equal to the upper quartile plus 1.5

times the interquartile range

75th PERCENTLE

MEDIAN

25th PERCENTLE

LOWER WHISKER--The smallest data value less

than or equal to the lower quartile minus

1.5 times the interquartile range

Figure 9. Distributions of simulated ground-water travel times for three wells at Picatinny Arsenal, Morris County, New Jersey. (Well locations are shown in fig. 8.) 


\section{Coastal Plain Aquifers}

The New Jersey Coastal Plain Physiographic Province is located in the southern part of the State. It includes all of New Jersey south and east of a line between Raritan Bay and the Delaware River near Trenton, encompassing about 60 percent of the State (fig. 1). The Coastal Plain is structurally a monocline that dips southeastward at a very low angle. The Coastal Plain sequence strikes northeast-southwest, parallel to the lower reach of the Delaware River. The bedrock below the Coastal Plain sediments consists of a complex of pre-Cretaceous igneous and metamorphic rocks. Cretaceous sediments unconformably overlie the bedrock (table 1). These sediments consist mainly of continental, coastal, and shallow marine gravels, sands, silts, and clays. Glauconitic sands, generally indicative of marine transgression, are commonplace in the upper Cretaceous sediments. Above the Cretaceous sediments is a series of Tertiary sediments that range in age from Paleocene through Miocene. They include sands, silts, and gravels, with common glauconitic zones. Pleistocene sediments, mainly fluvial sands and gravels, form a discontinuous veneer across the Coastal Plain (Zapecza, 1989). The sedimentary section is about $6,700 \mathrm{ft}$ thick in the southeasternmost part of Cape May County. These sediments comprise a series of layers of gravel and sand that function as aquifers and intervening layers of silt and clay that function as confining units.

The sediments of the New Jersey Coastal Plain are divided into a series of aquifers with intervening confining units that restrict the rate of movement and alter the direction of groundwater flow. Seven major aquifer systems are recognized, along with several that are of lesser importance and relatively limited extent. In many cases, hydrologic boundaries differ from the formal stratigraphic boundaries. For example, a geologic formation can act as an aquifer in one area and as a confining unit in another. A geologic formation can include more than one aquifer. A detailed description of the aquifers and confining units in the Coastal Plain, including maps of the altitude of the tops of units, thickness of units, outcrop areas of units, and extent of units is presented by Zapecza (1989).

In the Coastal Plain Physiographic Province (fig. 1), wells typically are screened in unconsolidated sediments consisting of gravel, sand, and silt. No community water-supply wells in the Coastal Plain are completed in bedrock aquifers. Water typically enters the well from pore spaces in the aquifer material surrounding the well opening. Ground water in wells with open intervals in aquifers in the Coastal Plain generally enters the system at land surface and flows downgradient through the unconfined system. In some cases, ground water flows underneath or through dense layers of fine sediments, where it becomes confined. A generalized hydrogeologic section through the major aquifers and confining units in the New Jersey Coastal Plain is shown in figure 10. Major aquifers within the Coastal Plain Province include (1) the Kirkwood-Cohansey aquifer system, (2) the Atlantic City 800-foot sand, (3) the Piney Point aquifer, (4) the Vincentown aquifer, (5) the Wenonah-Mount Laurel aquifer, (6) the Englishtown aquifer system, and (7) the Upper, Middle, and Lower Potomac-Raritan-Magothy aquifers. About 99 percent of community water-supply wells in the Coastal Plain Province tap these aquifers.

A confining unit is a formation or part of a formation in which ground-water flow is restricted relative to flow in the surrounding aquifers (Lohman and others, 1972). Hydraulic conductivities in confining units generally are distinctly lower than those in aquifers. Several major confining units are recognized within the Coastal Plain sediments in New Jersey. In order to 


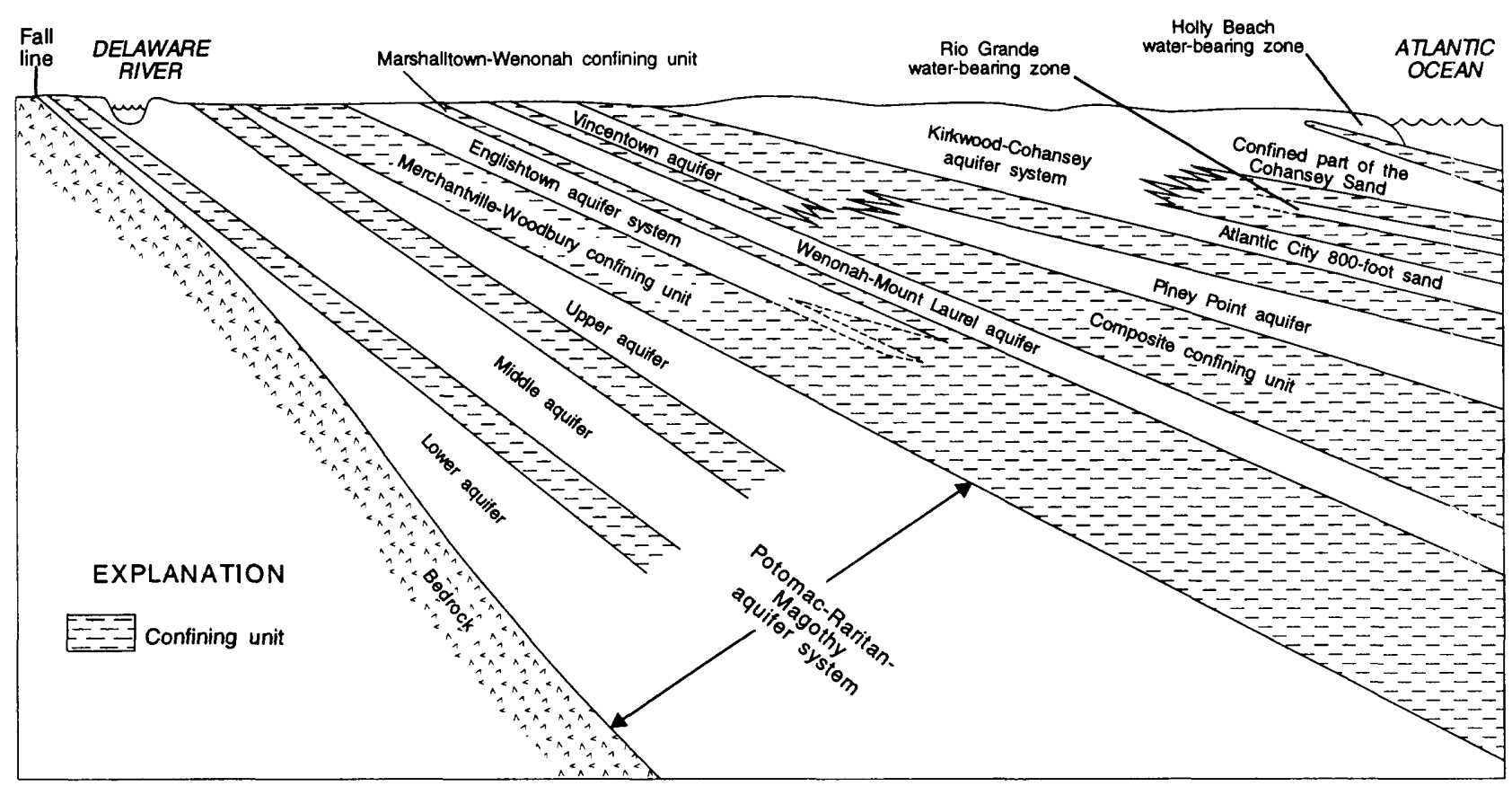

NOT TO SCALE

Figure 10. Generalized hydrogeologic section showing major aquifers and confing units in the New Jersey Coastal Plain. (Modified from Martin, in press.) 
be considered adequate to restrict flow to the degree needed to protect a well from contaminants discharged at land surface, these layers must be fairly extensive areally, have appreciable thickness, and have relatively low hydraulic conductivities.

Confining units can restrict the vertical movement of ground water to the extent that the minimum time of travel from land surface to the well through the confining unit far exceeds 12 years. These units include (1) the confining unit overlying the estuarine sand facies in part of Cape May County, (2) the confining unit overlying the Atlantic City 800-foot sand, (3) the composite confining unit, (4) the Marshalltown-Wenonah confining unit, and (5) the Merchantville-Woodbury confining unit. Other less extensive and leaky confining units are present. In confined aquifers in areas near where confining units crop out, pinch out, thin, or become more permeable, ground water may flow around or through the confining unit and reach a well in less than 12 years. In these cases, a well screened in the confined aquifer may be sensitive to contamination discharged at land surface.

The time of travel of ground water through the Merchantville-Woodbury confining unit (fig. 11) was simulated with a finite-difference flow model of the New Jersey Coastal Plain (D.A. Pope and others, U.S. Geological Survey, written commun., 1995). This confining unit separates the Upper Potomac-Raritan-Magothy aquifer from the Englishtown aquifer system. For all areas far from the outcrop area, the time of travel through the confining unit exceeds 500 years. Near the outcrop of the confining unit, simulation results indicate that ground water flows upward from the Upper Potomac-Raritan-Magothy aquifer and, therefore, time of travel from land surface to the well also likely is greater than 12 years.

The time of travel of ground water through the composite confining unit (fig. 12) also was simulated (D.A. Pope and others, U.S. Geological Survey, written commun., 1995). This confining unit separates the Wenonah-Mount Laurel aquifer from the Vincentown, the Piney Point, and other aquifers, depending on location within the Coastal Plain. The model grid was too coarse near the outcrop to accurately determine the time of travel from land surface to a well and, consequently, to determine whether wells are sensitive to contamination from land surface. The time of travel through the confining unit exceeds 100 years in all areas except near the confiningunit outcrop area. Similar travel times were simulated for the remaining three confining units listed above (D.A. Pope and others, U.S. Geological Survey, written commun., 1995). Wells screened in aquifers below all five of these confining units that are located far from the confiningunit outcrop area most likely are adequately confined and, therefore, insensitive to contaminants discharged at land surface.

A ground-water contributing area for a shallow well located in the outcrop area of the Potomac-Raritan-Magothy aquifer system is shown in figure 13. The contributing area was simulated with a finely discretized ground-water flow model by use of a particle-tracking analysis (Navoy, 1994). The figure distinguishes between areas where travel times from the water table to the well exceed 12 years and areas where they are less than or equal to 12 years. The well, Greenwich Township well 4 (15-69), is screened from 108 to $168 \mathrm{ft}$ below land surface in the Middle Potomac-Raritan-Magothy aquifer and is partly confined locally above the open interval. All water that enters the well within a radius of about 0.4 mi reaches the well within a 12 -year period. The maximum distance that the contributing area extends from the well is about $0.8 \mathrm{mi}$, although the travel time to the well is greater than 12 years. Results of this simulation indicate that 


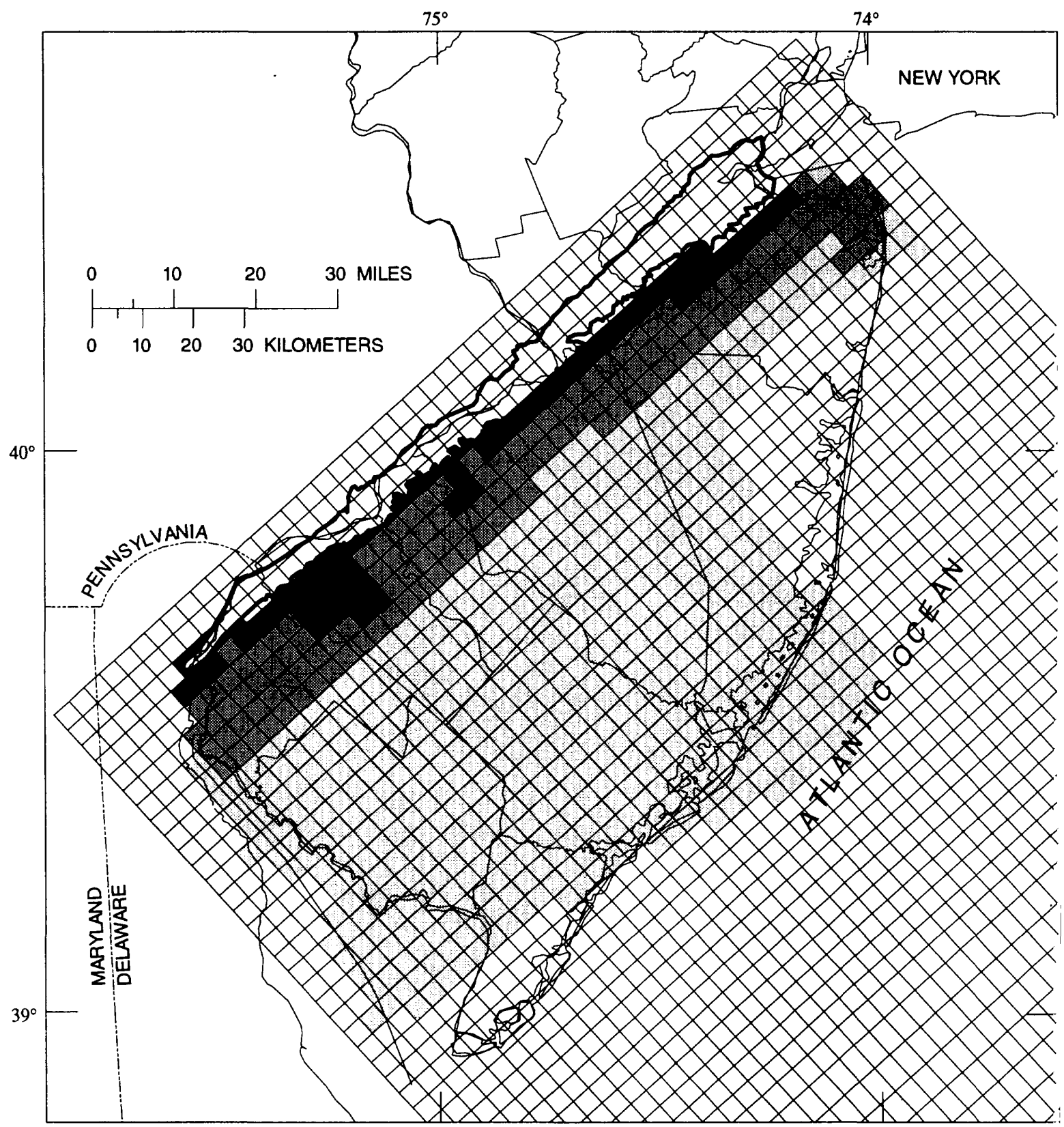

Base from U.S. Geological Survey digital data, $1: 2,000,000$, 1972, Universal Transverse Mercator Projection, Zone 18

EXPLANATION

TIME OF TRAVEL, IN YEARS

Less than or equal to 12

Greater than 12 to less than or equal to 50

Greater than 50 to less than or equal to 500

Greater than 500 to less than or equal to 5,000

Greater than 5,000

- EXTENT OF OUTCROP

Figure 11. Ground-water travel time through the Merchantville-Woodbury confining unit in the New Jersey Coastal Plain. (Modified from D.A. Pope and others, U.S. Geological Survey, written commun., 1995.) 


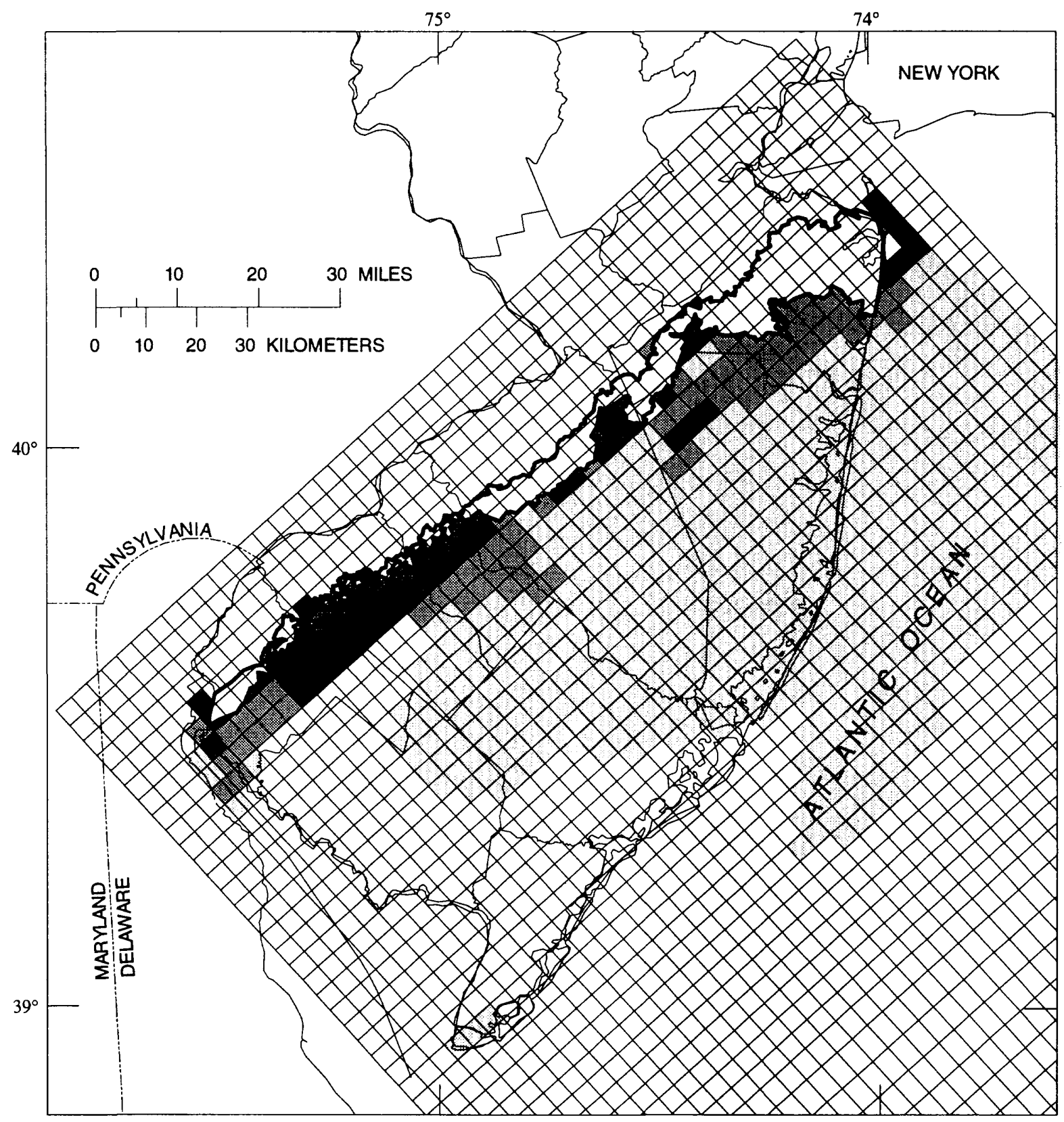

Base from U.S. Geological Survey digital data, $1: 2,000,000,1972$, Universal Transverse Mercator Projection, Zone 18

\section{EXPLANATION}

TIME OF TRAVEL, IN YEARS

Less than or equal to 12

Greater than 12 to less than or equal to 50

Greater than 50 to less than or equal to 500

Greater than 500 to less than or equal to 5,000

Greater than 5,000

- EXTENT OF OUTCROP

Figure 12. Ground-water travel time through the composite confining unit in the New Jersey Coastal Plain. (Modified from D.A. Pope and others, U.S. Geological Survey, written commun., 1995.) 

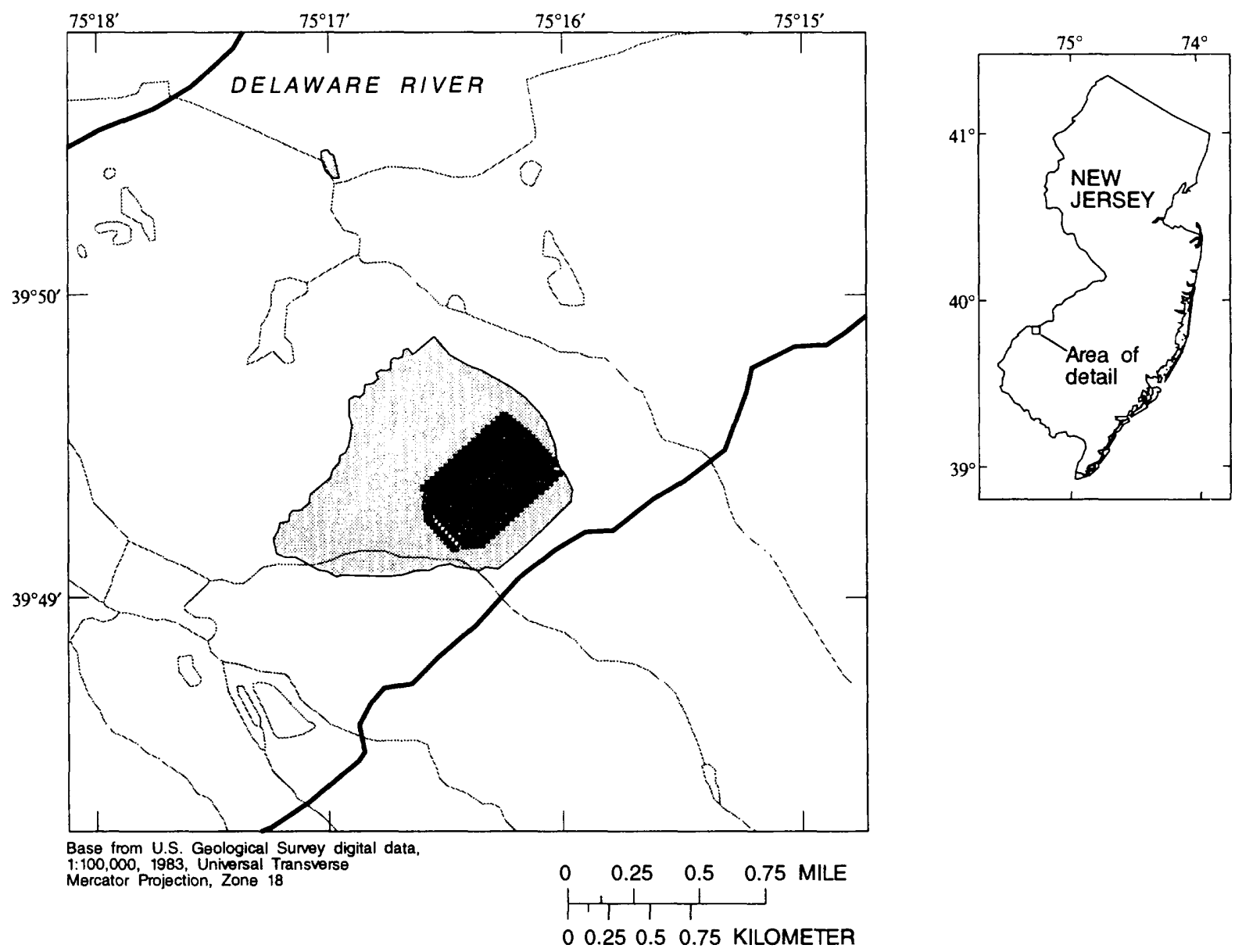

\section{EXPLANATION}

TIME OF TRAVEL, IN YEARS

Less than or equal to 12 years

Greater than 12 years

- EXTENT OF OUTCROP

RIVER OR STREAM

WELL 15-69

Figure 13. Simulated ground-water contributing area and travel time to well 15-69 in a Coastal Plain aquifer system, Gloucester County, New Jersey. (Modified from Navoy, 1994.) 
about 17 percent of the flow to the well travels from land surface through the leaky confining unit between the Upper and Middle Potomac-Raritan-Magothy aquifers to the well in less than 12 years.

A ground-water contributing area for a well downdip from the outcrop area of the Potomac-Raritan-Magothy aquifer system is shown in figure 14. The contributing area was delineated with the numerical model described above (Navoy, 1994). This well, Paulsboro Water Department well 4 (15-212), is screened in the Middle Potomac-Raritan-Magothy aquifer from 192 to $220 \mathrm{ft}$ below land surface. However, because a confining unit is present between the well's open interval and land surface, the contributing area does not surround the well, but is updip from the well in the outcrop area of the Potomac-Raritan-Magothy aquifer system. The time of travel from the water table to the well exceeds 12 years at all points within the contributing area.

A ground-water contributing area for a well screened adjacent to the outcrop area of the Potomac-Raritan-Magothy aquifer system is shown in figure 15. The well, Greenwich Township well 6 (15-348), is screened from 105 to $135 \mathrm{ft}$ below land surface in the Middle PotomacRaritan-Magothy aquifer. The contributing area was delineated with the same numerical model (Navoy, 1994). Results of the simulation indicate that the contributing area is greatly affected by the large volume of water withdrawn from this aquifer through well 15-69 (fig. 13). A statistical analysis of the 2,400 particles used in the model to represent ground-water flow paths indicates that the time of travel of all ground water flowing to the well is greater than 12 years.

A statistical analysis of travel times of 2,400 ground-water particles simulated with the numerical model (Navoy, 1994) was conducted for 10 wells in and near the outcrop of the Potomac-Raritan-Magothy aquifer system. The locations of the wells used in this simulation are shown in figure 16. The distribution of travel times indicates that although a well is located in the outcrop area, if it is sufficiently deep, the minimum time of travel may be greater than 12 years, as is the case for well 15-207, which is screened in the lower Potomac-Raritan-Magothy aquifer (fig. 17). Minimum travel time to other wells downdip from the outcrop, such as well 15-312, which is screened in the Middle Potomac-Raritan-Magothy aquifer about 0.4 mi downdip from the outcrop of the aquifer system, also may be greater than 12 years. Water traveled from the water table through or around the leaky confining unit between the Upper and Middle aquifers to this well in a minimum of about 30 years. Selected well-construction and time-of-travel data are presented in table 7 .

Wells screened in Coastal Plain aquifers were determined to be either (1) sensitive (wells in or less than $0.5 \mathrm{mi}$ downdip from outcrop areas of confined aquifers and wells in unconfined aquifers, where the minimum time of travel likely is less than 12 years) and (2) insensitive (wells in confined aquifers more than $0.5 \mathrm{mi}$ from the outcrop area, where the minimum time of travel likely is greater than 12 years). All wells screened in aquifers that do not crop out can be considered to be insensitive to contamination because the time of travel exceeds 12 years. These aquifers include the Atlantic City 800-foot sand, the Rio Grande water-bearing zone, the Piney Point aquifer, and, in Cape May County, the estuarine sand facies and the Cohansey Sand.

A zone between 0 and $0.5 \mathrm{mi}$ downdip from an outcrop area of an aquifer was considered to be an area of uncertainty where wells may be sensitive to contaminants discharged at land surface despite the presence of overlying confining units. In this area of local confinement, time of 

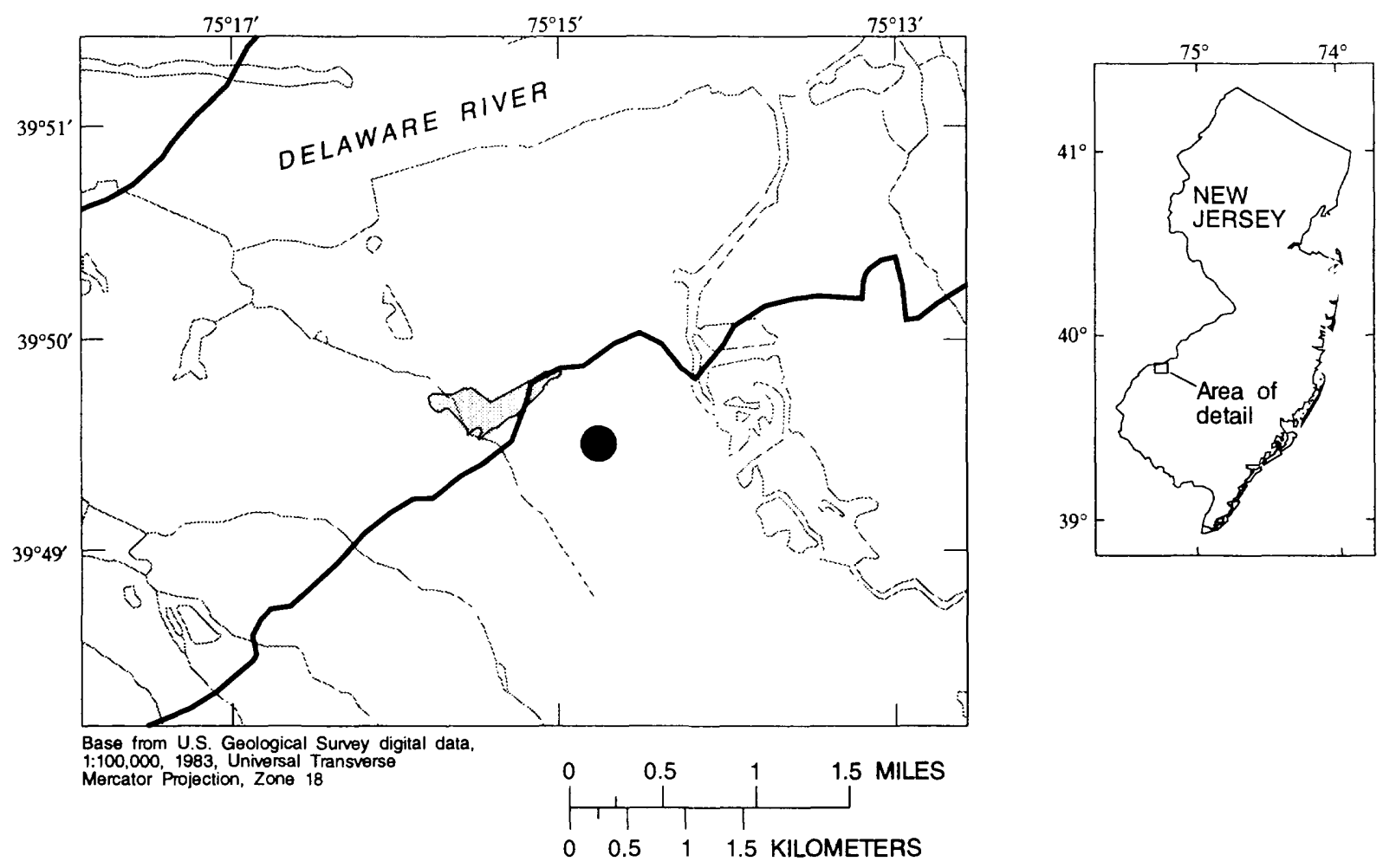

\section{EXPLANATION}

TIME OF TRAVEL, IN YEARS

Less than or equal to 12 years

Greater than 12 years

- EXTENT OF OUTCROP

- river or stream

WEL 15-212

Figure 14. Simulated ground-water contributing area and travel time to well 15-212 in a Coastal Plain aquifer system, Gloucester County, New Jersey. (Modified from Navoy, 1994.) 

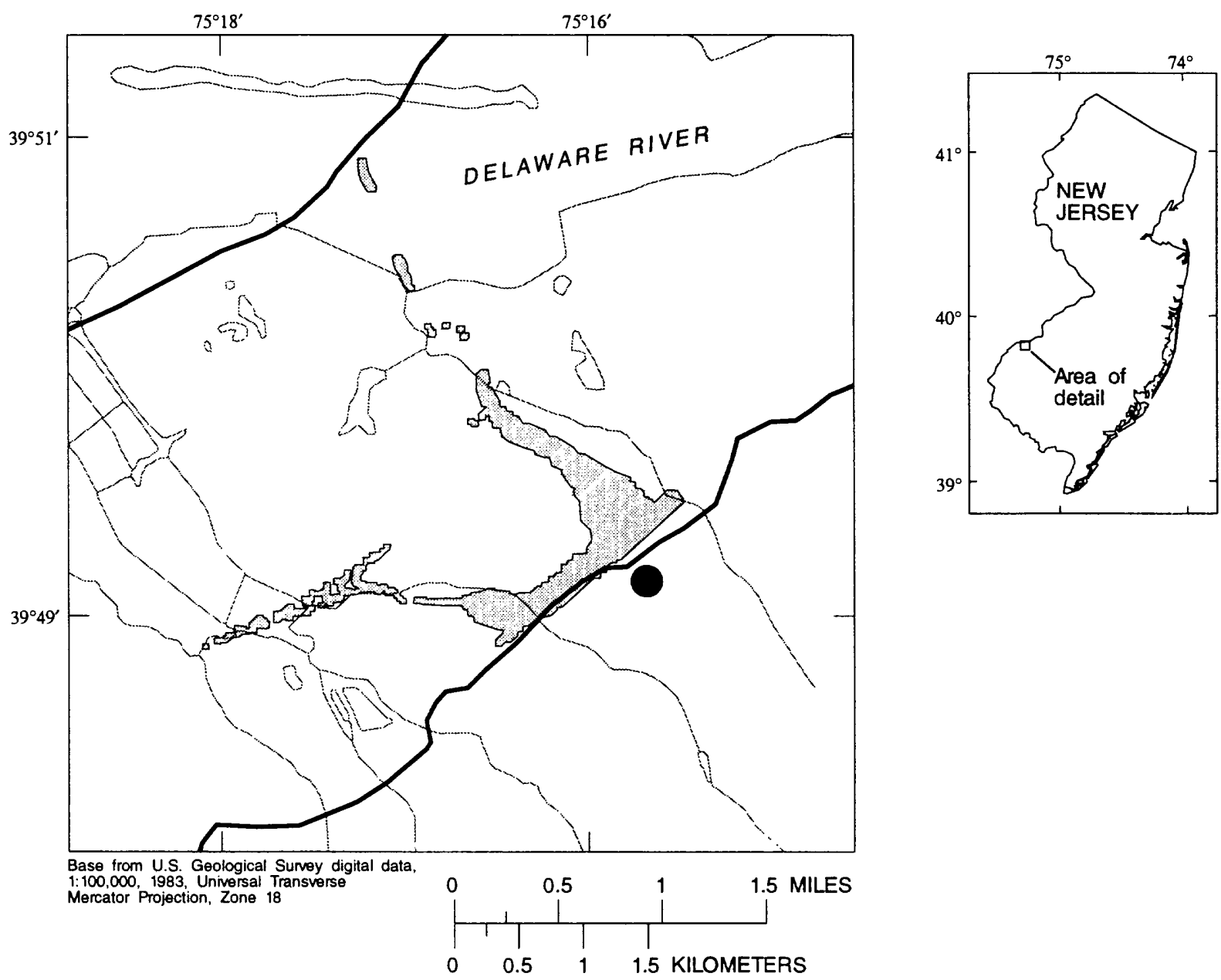

\section{EXPLANATION}

TIME OF TRAVEL, IN YEARS

Less than or equal to 12 years

Greater than 12 years

- EXTENT OF OUTCROP

- RIVER OR STREAM

WELL $15-348$

Figure 15. Simulated ground-water contributing area and travel time to well 15-348 in a Coastal Plain aquifer system, Gloucester County, New Jersey. (Modified from Navoy, 1994.) 

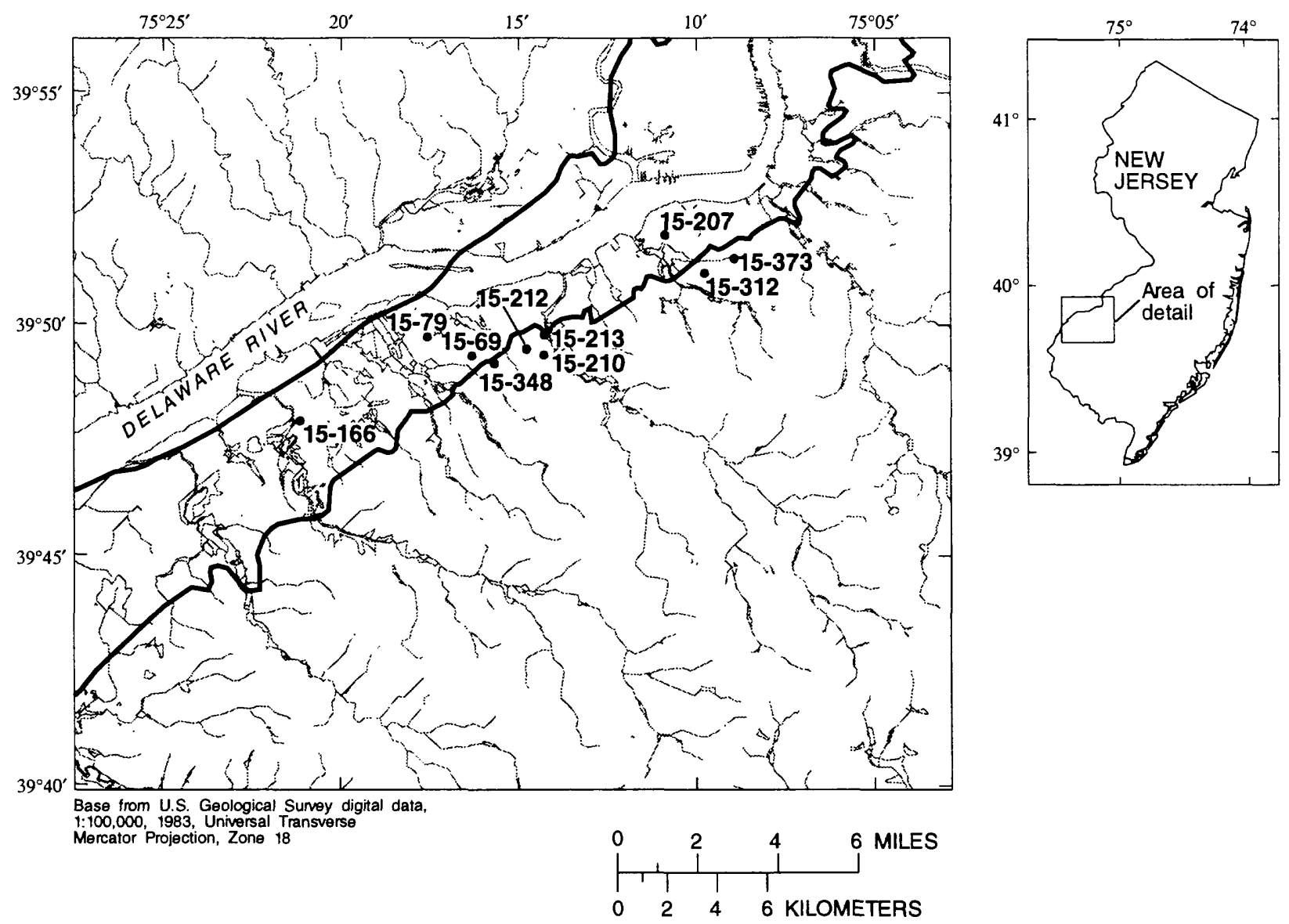

EXPLANATION

- EXTENT OF OUTCROP

- RIVER OR STREAM

•15-210 WeLL AND IDENTIFIER

\section{$\theta$}

Figure 16. Locations of selected wells in and downdip from the outcrop of the Potomac-Raritan-Magothy aquifer system in Gloucester County, New Jersey. 
(A) IN OUTCROP AREA

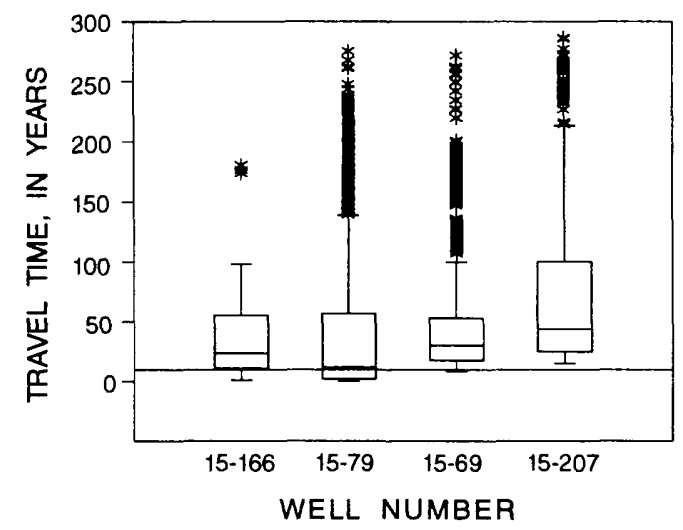

(B) DOWNDIP FROM OUTCROP AREA

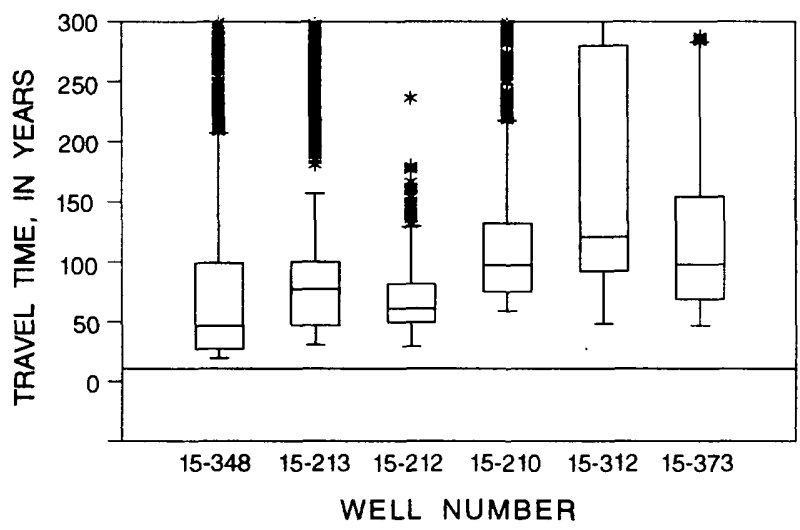

\section{EXPLANATION}

* OUTUER

UPPER WHISKER--The larger data value greater

than or equal to the upper quartile plus 1.5

times the interquartile range

75th PERCENTILE

MEDIAN

25th PERCENTILE

LOWER WHISKER--The smallest data value less

than or equal to the lower quartile minus

1.5 times the interquartile range

Figure 17. Distributions of ground-water travel times to selected wells in and downdip from the outcrop of the Potomac-Raritan-Magothy aquifer system, New Jersey. (Well locations are shown in fig. 16.) 
Table 7. Selected well-construction data and simulated ground-water travel times for community water-sur nly wells screened in the Potomac-Raritan-Magothy aquifer system in Gloucester County, New Jersey

$[<$, less than $]$

\begin{tabular}{|c|c|c|c|c|c|c|c|}
\hline \multirow{2}{*}{$\begin{array}{c}\text { Well } \\
\text { number }\end{array}$} & \multirow{2}{*}{$\begin{array}{c}\text { Well owner and local } \\
\text { identifier }\end{array}$} & \multirow{2}{*}{$\begin{array}{c}\text { Depth of open } \\
\text { interval, in feet } \\
\text { below land surface }\end{array}$} & \multirow[b]{2}{*}{ Aquifer } & \multirow{2}{*}{$\begin{array}{l}\text { Distance } \\
\text { from } \\
\text { outcrop } \\
\text { area, in } \\
\text { miles }\end{array}$} & \multicolumn{3}{|c|}{ Travel time, in years } \\
\hline & & & & & Minimum & Median & Maximum \\
\hline $15-166$ & PENNS GROVE WSC \#2 & $65-88$ & Middle & 0 & $<1$ & 23 & 180 \\
\hline 15- 79 & EI DUPONT REPAUNO \#6 & $84-109$ & Middle & 0 & $<1$ & 12 & 781 \\
\hline 15- 69 & GREENWICH WD \#4 & $108-168$ & Middle & 0 & 8 & 30 & 272 \\
\hline 15-207 & NATIONAL PK WD \#5 & $241-282$ & Lower & 0 & 15 & 44 & 774 \\
\hline $15-348$ & GREENWICH WD \#6 & $105-138$ & Middle & .11 & 19 & 46 & 634 \\
\hline $15-213$ & PAULSBORO WD \#5 & $135-175$ & Middle & .04 & 30 & 77 & 314 \\
\hline $15-212$ & PAULSBORO WD \#4 & $192-220$ & Middle & .42 & 29 & 61 & 962 \\
\hline $15-210$ & PAULSBORO WD \#6 & $185-230$ & Middle & .51 & 58 & 97 & 1,763 \\
\hline $15-312$ & W DEPTFORD WD \#6 & $322-372$ & Lower & .38 & 48 & 121 & 10,562 \\
\hline $15-373$ & W DEPTFORD WD \#7 & $323-366$ & Lower & .38 & 47 & 98 & 10,600 \\
\hline
\end{tabular}

travel to the well may be less than 12 years. In this situation, however, regulation of activities in the area surrounding the well would not protect the well from contaminants discharged at land surface because the area contributing water to the well is not near the well. Nevertheless, because of this uncertainty, the well is considered to be sensitive to contamination. A more detailed investigation in which site-specific information is examined would be needed to determine the sensitivity of this type of well.

For most aquifers in the Coastal Plain, any well in the outcrop area is considered to to sensitive to contamination, because confining units typically are thin or absent. In more com aquifer systems, such as the Potomac-Raritan-Magothy aquifer system, where several aquifers are separated by thin, leaky confining units in the outcrop area, wells in the lowest aquifer may be confined to the degree that water from land surface may not reach the well within 12 years. However, a detailed investigation is usually needed to determine areas contributing water to wells and corresponding travel times. In areas near the Atlantic Ocean or Delaware Bay, such as Cape May County, the lateral movement of saltwater resulting from the pumping of freshwater from the aquifer system may be more important than the introduction of contaminants from the land surface to the aquifer. 


\section{Bedrock Aquifers}

The Piedmont Physiographic Province trends northeast-southwest across the north-central and northeastern part of New Jersey (fig. 1). The southeastern edge of the province extends from the Delaware River near Trenton northeastward to Raritan Bay. The northwestern edge of the province is defined by a complex system of faults, beginning near Riegelsville and extending across the State. Structurally, the Piedmont Province is a monoclinal basin that strikes northeastsouthwest and dips irregularly to the northwest (Lewis and Kummel, 1912). The sedimentary section consists of upper Triassic and lower Jurassic rocks, mainly nonmarine sandstones, shales, and conglomerates (table 1). Within the sedimentary section are three series of basalt flows, which crop out and form an arcuate series of ridges in north-central New Jersey called the Watchung Mountains, and thick diabase sills that crop out in Hunterdon and Mercer Counties and along the western bank of the Hudson River (Lyttle and Epstein, 1987). The Triassic and Jurassic sequence is collectively known as the Newark Supergroup. Geologic units that function as major aquifers in the Piedmont Province include the Passaic Formation and other members of the Brunswick Group, and the Stockton Formation. Ground water is present in joints, faults, and intergranular spaces and along bedding surfaces in this system of rocks.

The Highlands Physiographic Province consists of a belt of exposed Precambrian igneous and metamorphic rocks that extend northeast-southwest across the north-central part of New Jersey (fig. 1). The boundary between the Highlands and Piedmont Provinces is an intricate system of faults, with the Highlands Province Precambrian rocks forming the uplifted side. Middle Proterozoic igneous rocks, including alaskite, albite-oligoclase granite, and amphibolites, and a broad range of metamorphic rocks such as gneiss and marble are found in the province (table 1). Locally, small areas of overlying lower Paleozoic rocks are present (Lyttle and Epstein, 1987). Geologic units that function as major aquifers in the Highlands Province are the Allentown dolomite, Leithsville Formation, and various components of the faulted Precambrian crystalline rock. Wells in these and other geologic units are developed along bedding surfaces and in joints, faults, and solution cavities characteristic of these rock units.

The Valley and Ridge Physiographic Province is west of the Highlands Province in the northwestern part of the State (fig. 1). In New Jersey it is bounded on the northwest by the Delaware River. The rocks of the province consist of tightly folded lower and middle Paleozoic sediments that strike northeast-southwest, parallel to the Delaware River (table 1). Typically, the folds are overthrown to the west, with inclined axial planes (Lewis and Kummel, 1912). Reverse faulting and thrusting in the regional strike direction has further complicated the geology of the province. The ages of the rocks that crop out in the New Jersey Valley and Ridge Province range from Cambrian to Devonian. The lower Paleozoic formations (Cambrian and Ordovician) are limestone and dolomite. Higher in the section, the middle Paleozoic (Silurian and Devonian) rocks tend to be shales and sandstones (Lyttle and Epstein, 1987). Geologic units that function as major aquifers in the Valley and Ridge Province include the Allentown dolomite and other members of the Kittatinny Supergroup. Ground water is present in joints, faults, intergranular spaces, and solution cavities, and along bedding surfaces in this system of rocks.

Bedrock aquifers are a source of public-water supply in the Valley and Ridge, Highlands, and Piedmont Provinces. Bedrock aquifer systems include all types of consolidated material and include sandstones, limestones, crystalline rocks, and other types of rock. These aquifers coincide 
with geologic units. Their capacity to produce water varies widely depending on the type of material present in the unit. Water typically enters the well through fractures, faults, solution cavities, and other openings within the geologic unit. Fracturing in bedrock generally is greatest near land surface and decreases with depth; therefore, much of the water available to wells comes from shallow depths within the bedrock. Due to the complexity of the geology in northern New Jersey, however, extensive aquifers and confining units similar to those in the Coastal Plain generally are not present, and local confinement is documented in only a few areas in this part of the State.

A cross-section through a typical bedrock aquifer system is shown in figure 18 . Water enters the bedrock aquifer system at land surface and flows toward discharge areas in valleys. Flow paths in the shallow weathered zone generally are relatively short. In the deeper rock layers, however, ground water flows through extensively fractured zones in the bedrock, and flow paths are much longer. The unconsolidated material above the bedrock may function locally as a confining unit. Similarly, competent unfractured bedrock strata also may act as confining units because flow through these zones in most cases is very slow. However, confinement does not necessarily protect the well from contaminants because the velocity of flow through fractures and faults typically is very high, and travel times can be very short. This characteristic, coupled with the fact that most bedrock wells have very long open intervals, indicates that the minimum trivel time of ground water from land surface to the well typically is less than 12 years.

A ground-water contributing area for a well open to a carbonate-rock aquifer in the Highlands Physiographic Province is shown in figure 19. This bedrock aquifer is below a glarial aquifer system that consists of stratified drift. The well, Morris County Municipal Utility Authority Flanders well 2 (27-1727), is open to the Leithsville Formation from 164 to $288 \mathrm{ft}$ below land surface. The contributing area was delineated with a discretized ground-water flow model by using a particle-tracking analysis to simulate flow paths (R.S. Nicholson, U.S. Geological Survey, written commun.,1996). The particles were started on the top face of the uppermost model layer and were forward-tracked to the discharge location. The distribution of travel times of particles from the water table to the well is shown in figure 20.

Results of this simulation indicate that recharge to the well originates in several areas, including near the valley walls and in upvalley areas, rather than near the well. Surface runoff that originates in upland areas may contribute to recharge near the valley walls. The location of the contributing area depends on several factors, including degree of local confinement, location of the well relative to the valley walls, and depth of the open interval. Ground water can flow through the glacial aquifer system and enter the underlying bedrock aquifer system. This well represents a situation in which a well in a bedrock aquifer can almost certainly be considered to be insensitive to contamination as a result of the presence of local confining layers above the we'l's open interval. In this case, the open interval is overlain by $164 \mathrm{ft}$ of stratified drift, till, weathered bedrock residuum, and low-permeability rock. The open intervals of most wells in New Jerser' open to bedrock aquifers are overlain by relatively little confining material. Figure 9 shows that the time of travel of ground water to this well is an outlier and is not typical of travel times to wells in bedrock aquifers. Even though the median time of travel of ground water from the water 


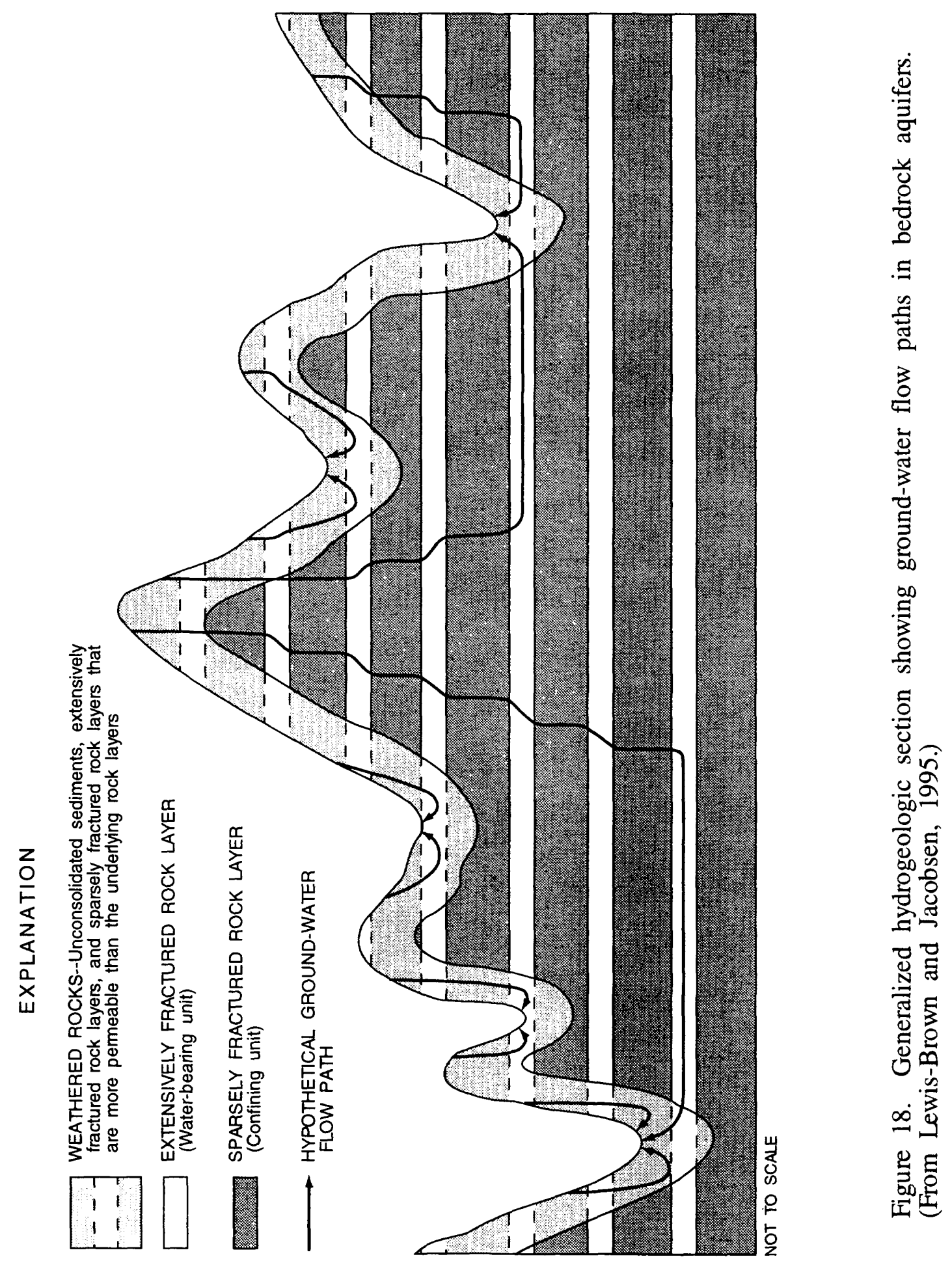




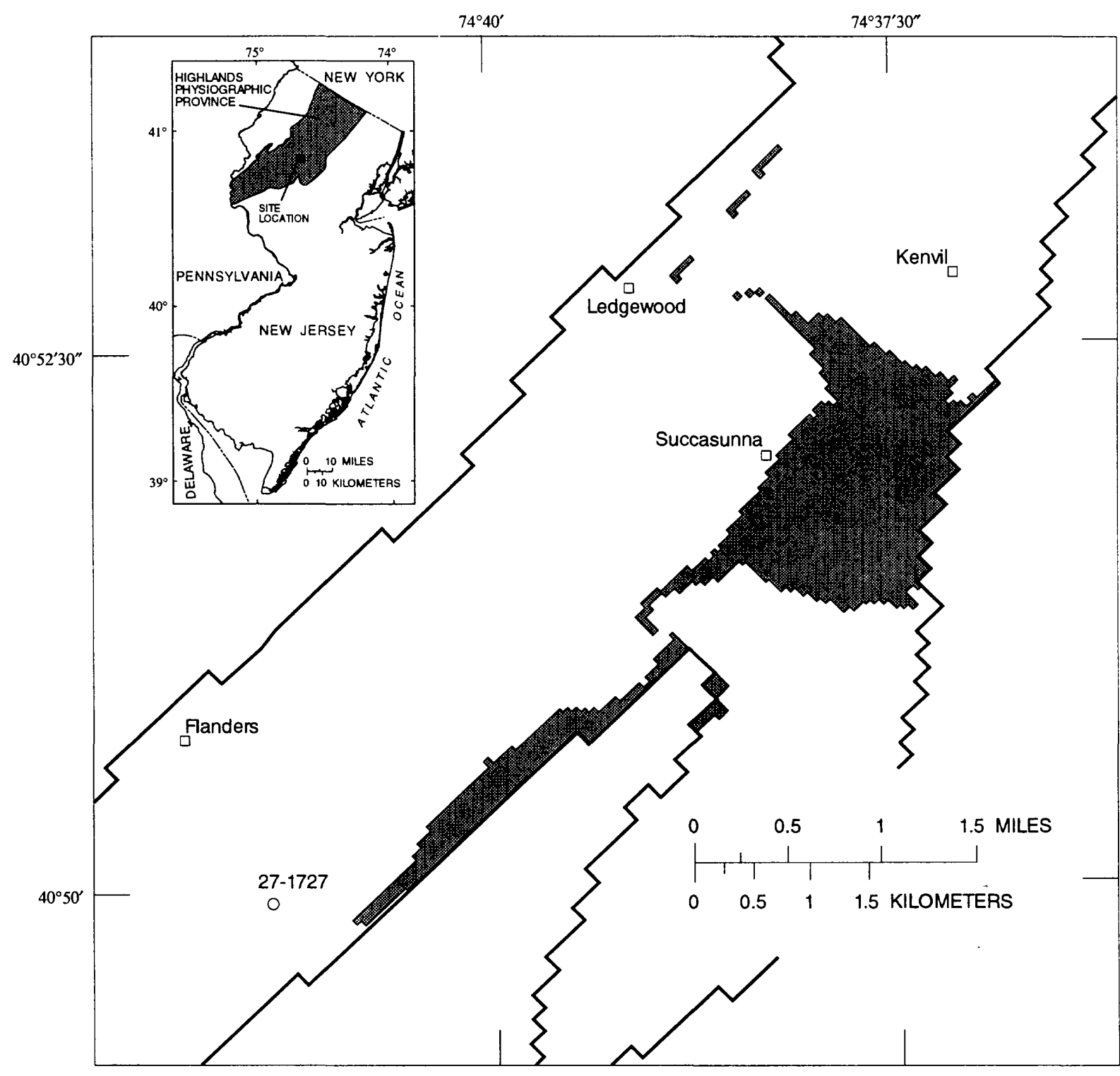

EXPLANATION

20.7 AREA CONTRIBUTING RECHARGE TO WELL

SIMULATED BOUNDARY OF VALEY-FILL

AND CARBONATE-ROCK AQUIFER

Figure 19. Simulated ground-water contributing area for well $27-1727$ in a bedrock aquifer system, Morris County, New Jersey. (From R.S. Nicholson, U.S. Geological Survey, written commun., 1996.) 

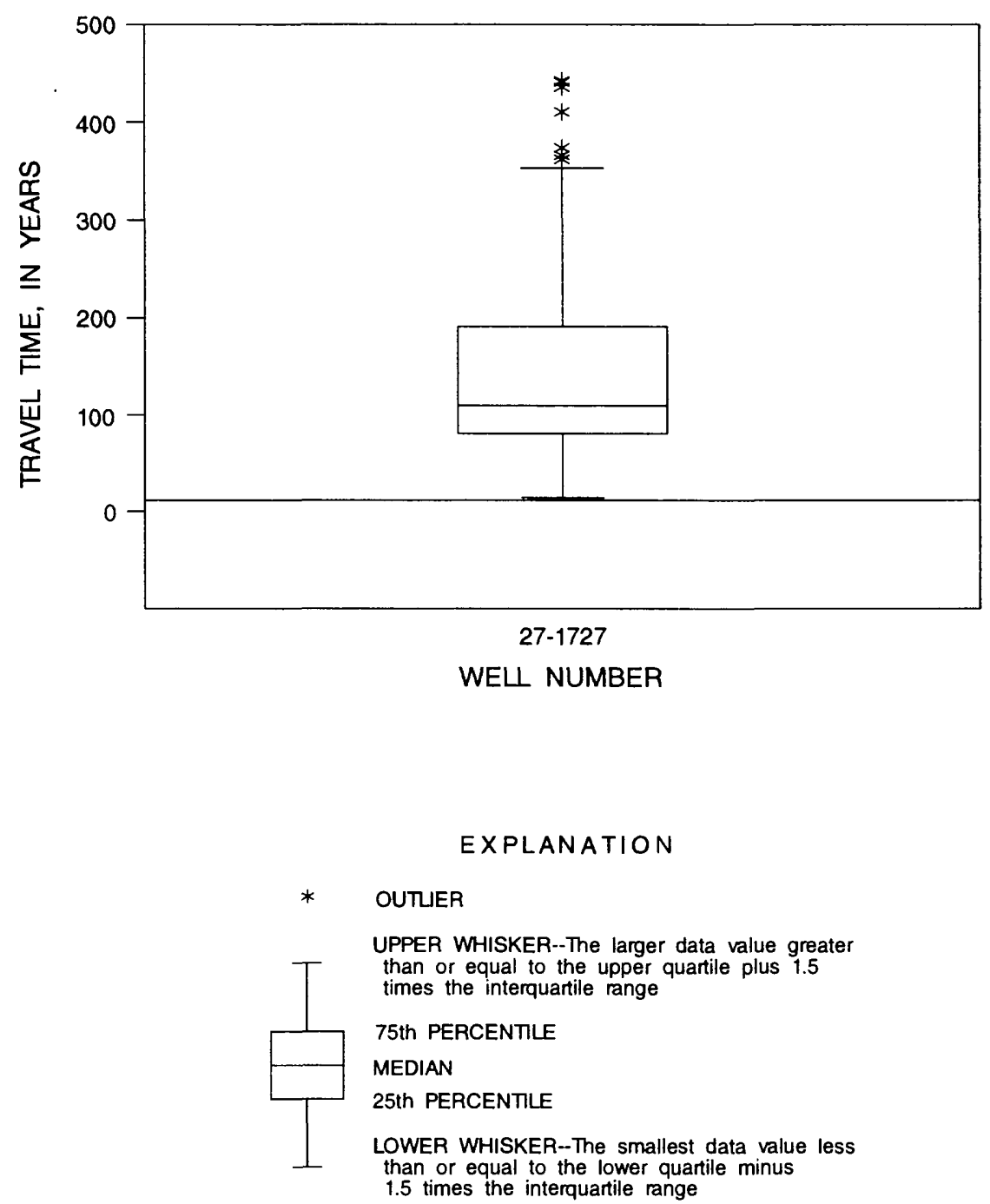

Figure 20. Distribution of ground-water travel times to a well in a bedrock aquifer system in Morris County, New Jersey. 
table to the well's open interval is 109 years, the minimum time of travel is 14 years, slightly greater than the 12-year criterion. Sclected well-construction characteristics and time-of-travel data for this well are presented in table 8.

Table 8. Selected well-construction data and simulated ground-water travel times for a community water-supply well open to a bedrock aquifer in Morris County, New Jersey

\begin{tabular}{ccccccc}
\hline $\begin{array}{c}\text { Well } \\
\text { number }\end{array}$ & $\begin{array}{c}\text { Depth of open interval, } \\
\text { in feet } \\
\text { below land surface }\end{array}$ & $\begin{array}{c}\text { Aquifer } \\
\text { type }\end{array}$ & Hydrogeologic characteristics & \multicolumn{2}{c}{ Travel time, in years } \\
\cline { 5 - 7 } & & & & Minimum & Median & Maximum \\
\hline \multirow{2}{*}{$27-1727$} & $164-288$ & Bedrock & $\begin{array}{c}\text { Open interval is overlain by } \\
98 \text { feet of glacial sediments }\end{array}$ & 14 & 109 & 764 \\
\hline
\end{tabular}

All wells whose open intervals are in bedrock aquifer systems are considered to be sensitive to contamination discharged at land surface because of (1) the geologic complexity of the aquifer systems and the lack of mappable, extensive confining units; (2) the relatively fast velocities of ground water in fractured zones within bedrock aquifers and the resulting short travel times from land surface to wells; and (3) the typical construction characteristics of wells in bedrock aquifers, which include long open intervals and short casing lengths.

\section{SUMMARY AND CONCLUSIONS}

An understanding of the sensitivity of wells to contamination from land surface is necessary to effectively manage New Jersey's ground-water resources and to protect its potablewater supply. The sensitivity of wells is related to hydrogeologic factors that determine the time of travel of water recharged from land surface to the open interval of the well. Hydrogeologic variables that were used for this assessment that can affect the time of travel are the presence of confining units above the open interval of the well and the depth to the top of the open interval. Sensitivity to contamination was evaluated for wells in three types of aquifer systems: glacial, Coastal Plain, and bedrock. Results of this evaluation can be used to delineate wellhead-protertion areas. The report also presents guidelines for determining the sensitivity to contamination of wells screened in confined aquifers.

The U.S. Geological Survey (USGS), in cooperation with the New Jersey Department of Environmental Protection (NJDEP), compiled well-construction and other well-attribute data for 2,598 community water-supply wells in New Jersey from existing data bases and files. A data base containing this information was developed and stored in a geographic information system as an ARC/INFO point coverage. The data base includes information from the USGS National Water Information System, Ground Water Site Inventory, data base stored in a point-attribute table. Information compiled from other data bases and files from various State agencies is stored in related INFO data files. Items stored in the data base include well-identification numbers, wrellconstruction characteristics, sensitivity ratings, location data, and owner information.

All wells for which sufficient information was available were evaluated for their sensitivity to contaminants discharged at land surface. The minimum data required to determine sensitivity or insensitivity to contamination include depth of the open interval, location of the well, and 
altitude of the top of the well. The sensitivity of 362 wells could not be determined either because one or more of these items was unknown or because the well was no longer used as a community water-supply well. Available ground-water flow models were used to simulate ground-water contributing areas, estimate the time of travel, and determine the sensitivity or insensitivity of wells in typical aquifer settings to contamination. Hydrogeologic variables that were used for this assessment include the presence or absence of confining units above the well's open interval, the location of the well relative to the outcrop area of the aquifer penetrated by the well, and the depth of the top of the open interval below land surface. Wells were grouped into three categories--those in glacial, Coastal Plain, and bedrock aquifers. Aquifer confinement, which protects ground water from contaminants discharged at land surface, is associated with the presence of overlying thick, areally extensive, impermeable units, which are common in the Coastal Plain but rarely are found in glacial and bedrock aquifer systems in New Jersey. A well is considered sufficiently confined to be designated insensitive when the vertical time of travel through a confining unit and the horizontal time of travel to the edge of a confining unit equals or exceeds 12 years at all points.

Simulated contributing areas of three wells in a typical glacial aquifer indicate that the minimum travel time of ground water from the water table to these wells generally is less than 12 years. Ground water in most glacial aquifer systems probably behaves similarly to that in these examples. Although thin confining units composed of fine-grained sediments are probably present in most valleys in New Jersey, most confining units in glacial sediments probably are leaky and, therefore, travel times from the land surface to the well most likely are small. All 245 wells open to glacial aquifers are considered to be sensitive to contamination discharged at land surface because of (1) the lack of mappable, extensive confining units; (2) the short travel times from land surface to the well; and (3) the typical construction characteristics of wells in glacial aquifers, which include shallow depth to the top of the open interval and shallow depth of well.

Coastal Plain sediments consist of a series of aquifers with intervening confining units that alter the direction of ground-water flow. Virtually all of the 1,351 community water-supply wells in the Coastal Plain Province withdraw water from these aquifers. For this analysis, two designations were possible for wells screened in Coastal Plain aquifer systems: (1) sensitive (wells in or less than $0.5 \mathrm{mi}$ downdip from outcrop areas of confined aquifers and wells in unconfined aquifers, where the minimum time of travel from land surface to the well likely is less than 12 years), or (2) insensitive (wells in confined aquifers greater than $0.5 \mathrm{mi}$ from the outcrop area where the minimum time of travel likely is greater than 12 years). All wells screened in aquifers that do not crop out were considered to be insensitive to contamination because the time of travel probably exceeds 12 years. These include wells screened in the Atlantic City 800 -foot sand, the Rio Grande water-bearing zone, the Piney Point aquifer, and other minor aquifers. Some areas between 0 and $0.5 \mathrm{mi}$ downdip from the outcrop area of an aquifer were considered to be areas of uncertainty where wells may be sensitive to contaminants discharged at land surface because travel time likely is less than 12 years despite the presence of overlying confining units. Ground water in such an area cannot be protected from contaminants discharged at land surface by establishing a wellhead-protection area because the ground-water contributing area is not adjacent to the well. Of the 1,351 water-supply wells in the Coastal Plain, 714 are considered to be insensitive to contamination because they are more than $0.5 \mathrm{mi}$ downdip from outcrop areas where travel times are likely greater than 12 years. 
Because the geology in northern New Jersey is complex, extensive aquifers and confining units similar to the those found in Coastal Plain generally are not present in bedrock, and local confinement is documented in only a few areas in this part of the State. Ground water that flows through fractures and faults typically has very high velocities, and travel times can be very stort despite local confinement. Short travel times coupled with the very long open intervals found in most bedrock wells indicate that the minimum travel time of ground water from land surface to the well is most often less than 12 years. All 1,002 wells with open intervals in bedrock aquifers are considered to be sensitive to contamination discharged at land surface because of (1) the geologic complexity of the aquifer systems and the lack of mappable, extensive confining units; (2) the relatively fast velocities of ground water in fractured zones within bedrock aquifers and the resulting short travel time from land surface to wells; and (3) the typical construction characteristics of wells in bedrock aquifers, which include long open intervals and short casing lengths. 


\section{REFERENCES CITED}

Barton, C., and Kozinski, J., 1991, Hydrogeology of the region of Greenwich Township, Gloucester County, New Jersey: U.S. Geological Survey Water-Resources Investigations Report 90-4198, $77 \mathrm{p}$.

Buddington, A.F., and Baker, D.R., 1961, Geology of Franklin and part of the Hamburg Quadrangles, New Jersey: U. S. Geological Survey Miscellaneous Geologic Investigations Series Map I-346.

Drake, A.A., Jr., 1967a, Geologic map of the Bloomsbury Quadrangle, New Jersey: U. S. Geological Survey Geologic Quadrangle Map GQ-595, scale 1:24,000.

Drake, A.A., Jr., 1967b, Geologic map of the Easton Quadrangle, New Jersey-Pennsylvania: U.S. Geological Survey Geologic Quadrangle Map GQ-594, scale 1:24,000.

Drake, A.A., Jr., 1992, Bedrock geologic map of the Newton West Quadrangle, Sussex and Warren Counties, New Jersey: U. S. Geological Survey Geologic Quadrangle Map GQ-1703, scale 1:24,000.

Drake, A.A., Jr., and Lyttle, P.T., 1985, Geologic map the Blairstown Quadrangle, Warren County, New Jersey: U. S. Geological Survey Geologic Quadrangle Map GQ-1585, scale $1: 24,000$.

Drake, A.A., Jr., and Monteverde, D.H., 1992, Bedrock geologic map of the Branchville Quadrangle, New Jersey: U. S. Geological Survey Geologic Quadrangle Map GQ-1700, scale 1:24,000.

Gronberg, J.A., Pucci, A.A., Jr., and Birkelo, B.A., 1991, Hydrogeologic framework of the Potomac-Raritan-Magothy aquifer system, northern Coastal Plain of New Jersey: U.S. Geological Survey Water-Resources Investigations Report 90-4016, 37 p.

Herman, G.C., and Mitchell, J.P., 1991, Bedrock geologic map of the Green Pond Mountain region from Dover to Greenwood Lake region, New Jersey: New Jersey Geological Survey Map Series 91-2, 3 pl.

Hendry, M.J., 1988, Do isotopes have a place in ground-water studies?: Ground Water, v. 26, no. 4 , p. 410-415.

Hill, M.C., Lennon, G.P., Brown, G.A., Hebson, C.S., and Rheaume, S.J., 1992, Geohydrology of, and simulation of ground-water flow in, the valley-fill deposits in the Ramapo River Valley, New Jersey: U. S. Geological Survey Water-Resources Investigations Report 90-4151, $92 \mathrm{p}$.

Lewis, J.A., Hochreiter, J.J., Jr., Barton, G.J., Kozinski, J., and Spitz, F.J., 1991, Hydrogeology of, and ground-water quality in, the Potomac-Raritan-Magothy aquifer system in the Logan Township region, Gloucester and Salem Counties, New Jersey: U. S. Geological Survey Water-Resources Investigations Report 90-4142, 92 p. 


\section{REFERENCES CITED--Continued}

Lewis, J.V., and Kummel, H.B., 1912, Geologic map of New Jersey: New Jersey Department of Conservation and Economic Development, Atlas sheet no. 40, scale 1:250,000.

Lewis-Brown, J.C., and Jacobsen, E., 1995, Hydrogeology and ground-water flow, fractured Mesozoic structural-basin rocks, Stony Brook, Belden, and Jacobs Creek drainage basins, west-central New Jersey: U.S. Geological Survey Water-Resources Investigations Report 94-4147, $83 \mathrm{p}$.

Lohman, S.W., and others, 1972, Definitions of selected ground-water terms--Revisions and conceptual refinements: U.S. Geological Survey Water-Supply Paper 1988, 21 p.

Lyttle, P.T., and Epstein, J.B., 1987, Geologic map of the Newark $1^{\circ} \times 2^{\circ}$ Quadrangle, New Jersey, Pennsylvania and New York: U. S. Geological Survey Miscellaneous Geologic Investigations Series Map I-1715.

Martin, Mary, in press, Ground-water flow in the New Jersey Coastal Plain: U. S. Geological Survey Professional Paper 1404-H.

Mathey, S.B., ed., 1990, National water information system user's manual volume 2, chapter 4. Ground-water site information system: U. S. Geological Survey Open-File Report 89-\$87, $287 \mathrm{p}$.

Miller, J.W., Jr., 1974, Geology and ground water resources of Sussex County and the Warrer County portion of the Tocks Island impact area: New Jersey Department of Environmental Protection, Division of Water Resources, Bureau of Geology and Topography Bulletin 73, $143 \mathrm{p}$.

National Research Council, 1993, Ground water vulnerability assessment--predicting relative contamination potential under conditions of uncertainty: Committee on Techniques foAssessing Ground-Water Vulnerability, Water Science and Technology Board, Commission on Geosciences, Environment, and Resources, National Academy of Sciences, Washington, D. C., National Academy Press, 204 p.

Navoy, A.S., in press, Use of flowpath simulation to determine contributing areas and travel times of nonpoint-source ground-water contamination, Gloucester County, New Jersey, in Morganwalp, D. W., and Aronson, D. A., eds., 1994, U.S. Geological Survey Toxic Substances Hydrology Program--Proceedings of the Technical Meeting, Colorado Springs, Colo., Sept. 20-24, 1993: U. S. Geological Survey Water-Resources Investigations Report 94-4015.

New Jersey Department of Environmental Protection, 1990, Generalized stratigraphic table for New Jersey: New Jersey Geological Survey Information Circular 1, 2 p.

New Jersey Department of Environmental Protection and Energy, 1991, New Jersey Well Head Protection Program plan: Trenton, New Jersey, New Jersey Department of Environmental Protection and Energy, December 1991, 109 p. 


\section{REFERENCES CITED--Continued}

Nicholson, R.S., McAuley, S.D., Barringer, J.L., and Gordon, A.D., 1996, Hydrogeology of, and ground-water flow in, a valley-fill and carbonate-rock aquifer system near Long Valley in the New Jersey Highlands: U. S. Geological Survey Water-Resources Investigations Report 93-4157.

Risser, D.W., and Madden, T.M., Jr., 1994, Evaluation of methods for delineating areas that contribute water to wells completed in valley-fill aquifers in Pennsylvania: U.S. Geological Survey Open-File Report 92-635, 82 p.

Sargent, B.P., Fusillo, T.V., Storck, D.A., and Smith, J.A., 1990, Assessment of contamination of ground water and surface water in the area of building 24, Picatinny Arsenal, New Jersey, 1986-87: U.S. Geological Survey Water-Resources Investigations Report 90-4057, 120 p.

Stanford, S.D., Witte, R.W., and Harper, D.P., 1990, Hydrogeologic character and thickness of glacial sediments in New Jersey, New Jersey Geological Survey Open-File Map 3, scale $1: 100,000$.

U.S. Environmental Protection Agency, 1992, A review of methods for assessing aquifer sensitivity and ground-water vulnerability to pesticides: U.S. Environmental Protection Agency, contract no. 68-co-0083, Raleigh, N. C., Geraghty and Miller, Inc.

Volkert, R.A., Monteverde, D.H., and Drake, A.A., Jr., 1989, Bedrock geologic map of the Stanhope Quadrangle, Sussex and Morris Counties, New Jersey: U. S. Geological Survey Geologic Quadrangle Map GQ-1671, scale 1:24,000.

Vowinkel, E.F., and Battaglin, W.A., 1989, Hydrogeological, well-construction, and land-use factors that can affect the evaluation of regional ground-water quality, in Proceedings of the International Association of Hydrological Sciences, IASH 182, Baltimore, Md., p. 69-77.

Vowinkel, E.F., Clawges, R.M., and Uchrin, C.G., 1994, Evaluation of the vulnerability of water from public supply wells in New Jersey to contamination by pesticides, in Weigmann, D.L., ed., New directions in pesticide research, development, management, and policy: Proceedings of the Fourth National Conference on Pesticides, November 1993, Blacksburg, Va., p. 496-510.

Zapecza, O.S., 1989, Hydrogeologic framework of the New Jersey Coastal Plain: U. S. Geological Survey Professional Paper 1404-B, 49 p., 24 pl. 